\title{
Balanocrinus and other crinoids from Late Jurassic mudstones of France and Switzerland
}

\author{
Hans Hess
}

Received: 20 May 2013/ Accepted: 25 July 2013/Published online: 21 August 2013

(C) Akademie der Naturwissenschaften Schweiz (SCNAT) 2013

\begin{abstract}
Late Jurassic mudstones of France and Switzerland are rich in remains of the isocrinid Balanocrinus. From the early Late Oxfordian of Savigna (Département du Jura, France) Balanocrinus brachiospina is described as new; the material includes all growth stages and skeletal elements, allowing the reconstruction of the animal and description of ontogenetic changes. The remains of $\mathrm{Bal}$ anocrinus from Savigna are compared with Balanocrinus subteres (MüNSTER in GoldFuss) from the Middle Oxfordian sponge facies of Holderbank (northern Switzerland) and with Balanocrinus pentagonalis (GoldFuss) from the Early Oxfordian of Les Rouges-Terres (Canton of Jura, Switzerland. The present material enables improved diagnoses of the two common Oxfordian species, B. subteres and $B$. pentagonalis. The Savigna locality includes two rare new comatulids, Palaeocomaster musculosus n. sp. and Andymetra donovani n. sp. The late Early Oxfordian locality of Andelot-Morval near Saint-Amour (Département du Jura, France) furnished B. brachiospina n. sp., and the comatulids are represented by Palaeocomaster musculosus n. sp., Archaeometra scrobiculata (GoLDFuss) and Semiometra petitclerci (CAILLET). The paracomatulid Paracomatula morator n. sp. from Andelot is the last representative of the group. Numerous remains of the cyrtocrinid Tetracrinus galei n. sp. supplement the Andelot fauna.
\end{abstract}

Keywords Crinoids · Oxfordian · Jura - Taxonomy

H. Hess $(\bowtie)$

Naturhistorisches Museum Basel, Augustinergasse 2,

4001 Basel, Switzerland

e-mail: hans.hess@bluewin.ch

\section{Introduction}

The present paper was initiated by a large collection of crinoid ossicles from early Late Oxfordian marly clays exposed near the village of Savigna, French Jura (Gale 2011). This locality is rich in remains of all classes of echinoderms of which ophiuroids (Hess 1966) and asteroids (Gale 2011) have been previously described. The bulk of the crinoid ossicles belongs to Balanocrinus, a genus that dominated Jurassic mudstones (Loriol 1887; Hess 1975; Simms 1989; Thuy et al. 2011), but also occurs in other types of rock. The material from Savigna allows a detailed analysis and reconstruction of a species whose column resembles that of $B$. subteres, the type species of the genus. The Early Oxfordian locality of Andelot-Morval in the French Jura, also sampled by A. S. Gale, furnished the same Balanocrinus, although in smaller numbers. The Savigna and Andelot Balanocrinus species is compared with Balanocrinus subteres from the Middle Oxfordian Birmenstorf Member of the Chalch Quarry, Holderbank, Switzerland. Balanocrinus pentagonalis from the Early Oxfordian Renggeri Member occurs in sediments similar to those of Savigna, and corresponding ossicles from Les Rouges-Terres in the Swiss Jura are used for a comparison. The dominance, at Savigna and Andelot, of Balanocrinus with its distinctive ossicles permits a clear differentiation from a species of Isocrinus also present and described in the following. Well-preserved material of Balanocrinus gracilis from the Lower Jurassic (Pliensbachian, Thuy et al. 2011) further adds to the knowledge of Jurassic Balanocrinus; and corresponding remains are described in a parallel paper (Hess 2013a). Included in the study are some comatulids from Savigna and Andelot that substantially increase the knowledge on the early history of these crinoids. Their radiation in the Jurassic is discussed in a 
parallel paper (Hess 2013b). Surprisingly, the locality of Andelot furnished a considerable number of remains of the cyrtocrinid Tetracrinus galei $\mathrm{n}$. sp. The co-occurrence of a cyrtocrinid, a large comatulid and a gracile Balanocrinus in mudstone is most unusual.

\section{Localities and material (Fig. 1)}

The material described in the present paper comes from four localities in the French and Swiss Jura (see Hess 2013a, fig. 1). (1) The locality of Savigna was first sampled by the author for ophiuroids (Hess 1966). It was further explored in more detail by Gale who took nearly a ton of calcareous clay from three levels $(1,2 a, 2 b)$ that served for his description of the asteroids (Gale 2011). Some arm fragments with pinnules are from the upper part of the Savigna outcrops (Petit Buis) in the higher part of the Couches d'Effingen, and the sample is from about $8 \mathrm{~m}$ beneath the summit. The mudstones and marly limestones of the area belong to the lower Couches d'Effingen (Enay 1966). Gale (2011) assigned the successions to the Stenocycloides Subzone of the Bifurcatus Zone (early Late Oxfordian). According to Gygi (2000) the Bifurcatus Zone is of Middle Oxfordian age, and only the lowest part of the Bimammatum Zone (Hypselum Subzone) is Late Oxfordian in age. The author picked the residues provided by A. S. Gale for the crinoids described in the present paper. The numerous ophiuroid ossicles are studied by Ben Thuy. (2) The site of Andelot-Morval in the French Jura was sampled by A. S. Gale (Fig. 1). The outcrop near the hamlet of Andelot-lès-Saint-Amour is in the area of a disused clay pit, now two fish ponds. The crinoid material described here was obtained from level E, sample 3 of the section, where $300 \mathrm{~kg}$ of the calcareous clay was taken and processed, resulting not only in remains of $B$. brachiospina $\mathrm{n}$. sp. and Tetracrinus galei n. sp., but also some comatulids. Surface picking from the same part of the section furnished some large and well-preserved Archaeometra scrobiculata (GoldFuss). Andelot yielded a Cardioceras alphacordatum fauna (Early Oxfordian) from the base (A), and the highest beds (E) represent the "Couches de Passages" (Enay 1966), also assigned to Early Oxfordian. (3) Mudstones of the Renggeri Member (Early Oxfordian, Mariae Zone) are exposed at the surface of a pasture at Les Rouges-Terres near Saignelégier in the Swiss Jura. The locality was first sampled by the author for ophiuroids (Hess 1960) and again recently by the author and A. S. Gale who collected some $50 \mathrm{~kg}$ of material for the present study. (4) Fossiliferous marlstones of the Middle Oxfordian Birmenstorf Member (Transversarium Zone) are exposed at the Chalch Quarry at Holderbank, Canton Aargau, northern Switzerland (Hess and Spichiger 2001). The spongiferous Birmenstorf Member underlies the much thicker Effingen Member assigned to the Bifurcatus and lower part of the Bimammatum Zones.

The isolated and washed crinoid ossicles were further cleaned in an ultrasonic bath. Most photographs were made at the Zentrum für Mikroskopie of the University of Basel by E. Bieler, using a Philips XL30 ESEM and gold-coated samples. The large specimens were photographed by the author by light microscopy.

Repositories. $\mathrm{M}=$ Naturhistorisches Museum Basel (NMB); SMNS = Staatliches Museum für Naturkunde, Stuttgart.

\section{Systematic palaeontology}

Remark. Taxonomy, authorship of taxa with references and terminology after Hess and Messing (2011), except placement of Paracomatulidae.

Order Isocrinida Sieverts-DoReck, 1952.

Suborder Isocrinina SIEverTs-DoReCK, 1952.

Family Isocrinidae GISLÉN 1924.

Subfamily Balanocrininae Roux, 1981.

Balanocrinus Agassiz in Desor, 1845.

Balanocrinus gracilis (CHARLESWORTH, 1847), see Hess 2013a, Fig. 2.

1847 Pentacrinus gracilis Charlesworth, p. 98, pl. 9. 1989 Balanocrinus gracilis (CHARLESWORTH), Simms, p. 65; pl. 11, fig. 19-22, 25, 26; pl. 12, fig. 1, 2, 7; text-fig. 10, $17-20$.

2011 Balanocrinus gracilis (CHARLESwORTH), Thuy et al., p. 175 , fig. $3 \mathrm{a}-\mathrm{c}$.

2011 Balanocrinus gracilis (CHARLESWORTH), Hess and Messing, p. 58, fig. 301i.

Material. See Hess 2013a.

Diagnosis (extended from Simms 1989, p. 66). Moderate to large Balanocrinus (columnal diameter $>6 \mathrm{~mm}$ ); 29-40 columnals per noditaxis. Cirral scar width 33-49\% of nodal diameter. Distal cirrals only moderately compressed, with smooth latera. Basals separate, low triangular externally in adult specimens. Embayed synarthry between primibrachials. First pinnule on second secundibrachial. First synostosis between third and fourth secundibrachial. Secundibrachials aborally rounded.

Description. See Hess 2013a.

Remark. Although smaller than the specimens described by Simms (1989) from the Pliensbachian of England the Sedan specimens agree well in their characters.

Balanocrinus pentagonalis (GoLDFuss, 1831), Fig. 2. 


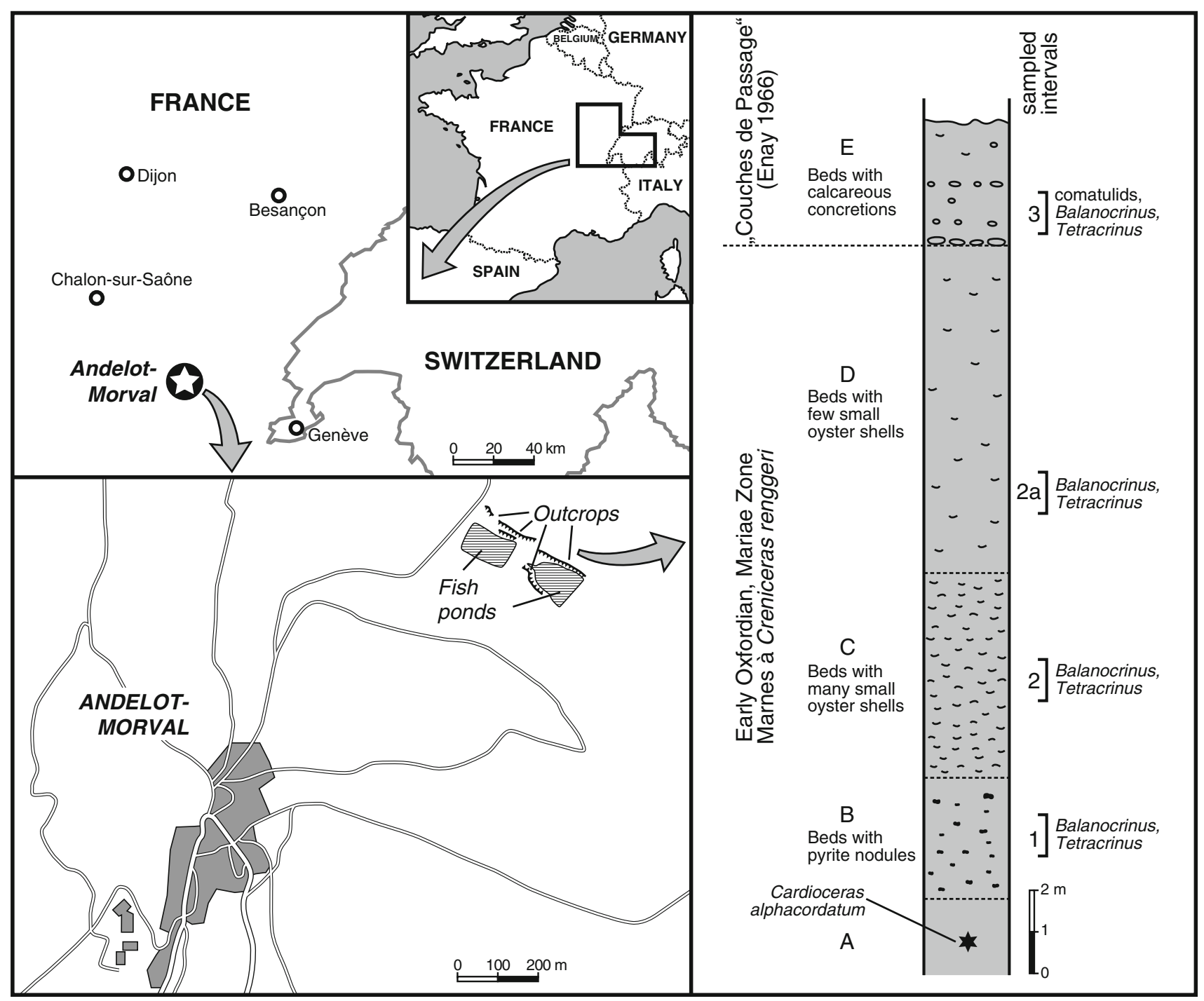

Fig. 1 Location of the Andelot-Morval site and profile raised by A. S. Gale. Lithology is all calcareous clay; pyrite nodules and calcareous concretions or oysters are partly abundant. The crinoids

1831 Pentacrinites pentagonalis GoLDFuss 1826-1833, p. 175.

1876 Pentacrinus pentagonalis GoldFuss, Quenstedt, p. 241, pl. 99, fig. 1-17.

1879 Balanocrinus pentagonalis (GoldFuss), Loriol, p. 168, pl. 17, fig. 17-28.

1887 Balanocrinus pentagonalis (GoldFuss), Loriol, p. 327, pl. 188-190.

1972 Balanocrinus pentagonalis (GoLDFuss), Hess, p. 199, fig. 4-10.

1975 Balanocrinus pentagonalis (GoldFuss), Hess, p. 58, pl. 20, fig. 22-26; pl. 24, fig. 4; pl. 45, fig. 12-15.

1979a Balanocrinus pentagonalis (GoLDFuss), Klikushin, p. 91, pl. 12, fig. 1-3.

1979b Balanocrinus (Margocrinus) pentagonalis (GoLDFuss), Klikushin, p. 94, fig. 2a-b, 3a. described in the present paper are from sample 3 at the top of the outcrop. The other samples also contain crinoids, as indicated, as well as asteroids that will be described by $A$. S. Gale (in preparation)

1982 Margocrinus pentagonalis (GoLDFuss), Klikushin, p. 302, pl. 5, fig. 1-3.

1992 Margocrinus pentagonalis (GoldFuss), Klikushin, p. 92, pl. 6, fig. 4-9.

2011 Balanocrinus pentagonalis (GolDFuss), Hess and Messing, p. 56, fig. 301d-e.

Material. This species is common in mudstones of the Early Oxfordian Renggeri Member of the Swiss and French Jura. However, only parts of the column were available for the detailed descriptions in the classic monographs of Loriol (1879, 1887). From Les Rouges-Terres Hess figured some pinnulars (1975, pl. 45, fig. 12-15) and in 1972 a radial and some brachials (fig. 4-10). The presently available material obtained from processing about $50 \mathrm{~kg}$ clay includes several thousand columnals and pluricolumnals as well as a number 


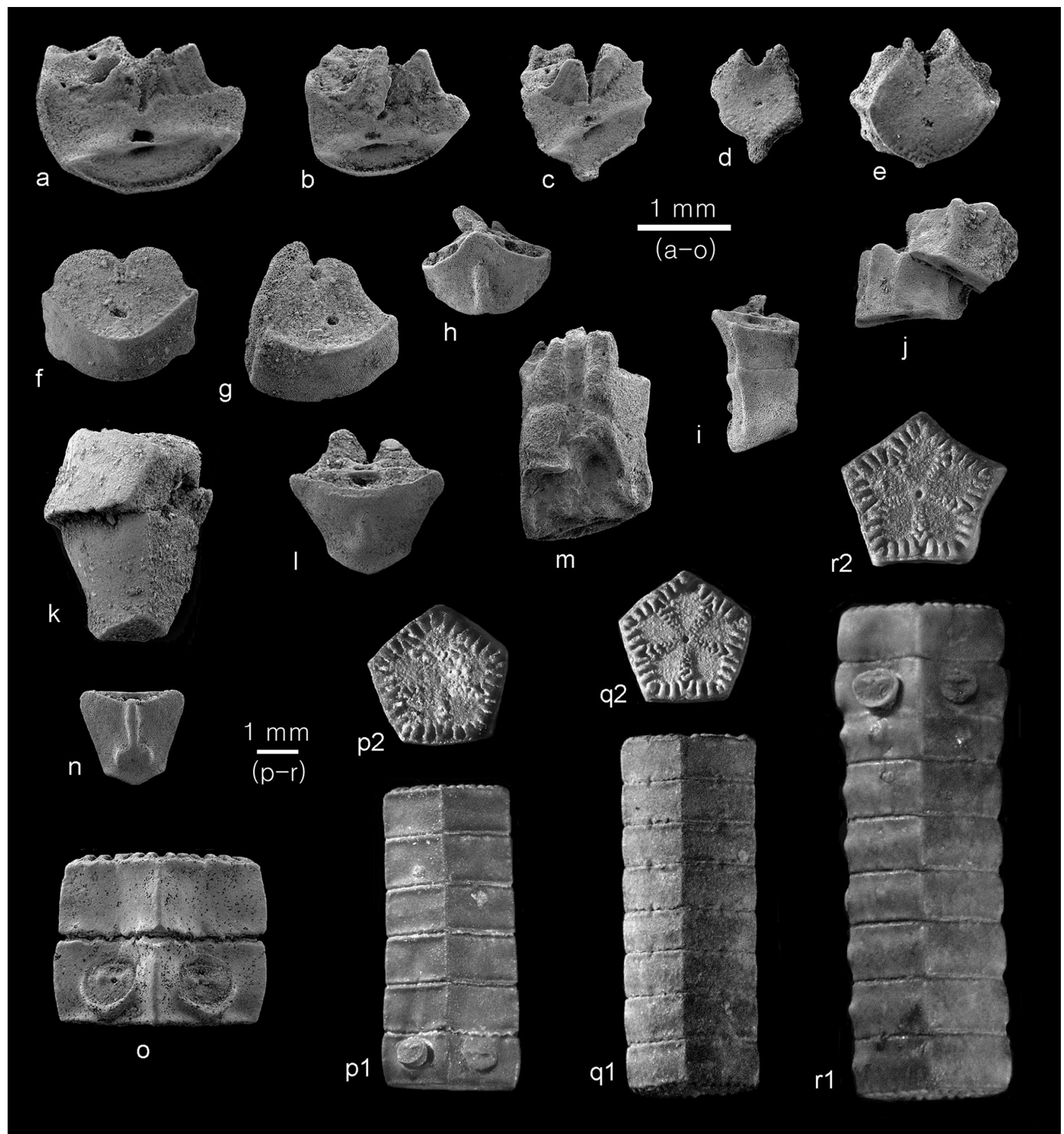

Fig. 2 Balanocrinus pentagonalis (GoLDFuss), Early Oxfordian, Les Rouges-Terres. a Distal facet of wide proximal secundibrachial, other facet muscular; M11323. b Distal facet of secundibrachial from proximal part of arm, other facet muscular; M11324. c Distal facet of secundibrachial from median part of arm with short nipple, other side muscular. M11325. d Distal, synostosial facet of secundibrachial with nipple, other facet muscular without pinnule socket; M11326. e Proximal, symmmorphial facet of secundibrachial with small nipple, other side muscular with pinnule socket; M11327. f Distal, synostosial facet of symmetric first primibrachial, M11328. g Distal, synostosial facet of asymmetric first primibrachial, M11329. h Aboral side of second primibrachial with crest, M11330. i Aboral view of two secundibrachials with crest joined by synostosis, facet of upper brachial muscular with pinnule socket; M11332. j Aboral view of two slightly displaced secundibrachials with crest, all facets muscular; M11331. k Aboral-lateral view of radial with attached first primibrachial, articulation with neighbouring ossicles synostosial; M11334. I Aboral view of radial with forked crest, M11335. m Adoral view of fused first and second primibrachials, second primibrachial not axillary, pinnule socket on the non-axillary second primibrachial at upper left, articulation with neighbouring ossicles at right by flat synostosis with weak ridges; M11337. n Aboral view of radial with strong, forked crest, muscle fossae at right angle to aboral side and poorly visible, M11336. o Lateral view of nodal with supranodal, M11333. p Angular pluricolumnals with nodal, M11412, p1 lateral, p2 upper facet. q Angular pluricolumnal of internodals, M11413, q1 lateral, note radial pores, q2 upper facet. $\mathbf{r}$ Angular, knobby pluricolunmnal with nodal, M11414, r1 lateral, r2 upper facet 
of radials, primibrachials and secundibrachials of several types. However, no closed basal circlet has been found. Radials number 27, 18 of which have a more or less developed crest. There are 34 first primibrachials, half of them with smooth aboral surface and the other half with a weak crest. Second primibrachials total 11, 6 of them with a crest. Secondary axillaries with a proximal muscular facet number 25, 19 of them with a crest. Many of the ossicles are partly covered by fine grains of quartz, but are otherwise well preserved,..

Diagnosis (for a previous diagnosis see Hess 1972, p. 200). Column pentagonal to pentastellate proximally, with sharp interradii and smooth latera that may carry a few or a row of granules at midline, latus may be slightly convex, with interradial knobs; noditaxis of 11-15; nodals and internodals of similar height and diameter; cirrus sockets circular to elliptical, directed slightly upwards, cirral scar width about one-third of nodal diameter; cupules mostly weak or lacking; symplectial facets of internodals with strong marginal crenulae, ribbons of adradial crenulae well produced only near margin, may be irregular; fossulae weakly developed. Radials smooth or with aboral crest that may be forked proximally, articular facet with rather low muscle fossae. Basals probably in contact. Primibrachials smooth or with mostly weak aboral crest, connected by weak cryptosynarthry or synostosis. Neighbouring primibrachials and proximal secundibrachials may be in contact by synostosis. Proximal secundibrachials aborally rounded and mostly symmetric; distal secundibrachials with aboral nipple or weak crest. Synostoses or cryptosyzgies common, symmorphies rather rare. Arms branched a second time..

Description. Columnals were amply described in the classic monographs by Loriol (1879, 1887). Most of the columnals from Les Rouges-Terres have smooth, straight latera (Fig. 2p, q), but specimens with slightly convex, knobby latus also occur (Fig. 2r). Columnals with latera ornamented by granules are exceptional. Cirrus sockets have a distinct aboral lip (Fig. 2o) and are directed slightly upwards; the supranodal shows a cupule for reception of the adpressed proximal part of the cirrus. Cirral scar width is approximately one-third of nodal diameter. Complete noditaxes have not been found at Les Rouges-Terres, but Loriol (1887, p. 329) mentioned a range of 11-15. Pluricolumnals with radial pores are rare (Fig. $2 q$ ), as are columnal facets with fossulae. Basal circlets or isolated basals have not been found, but the shape of the radials suggests that basals were in contact. The radials are trapezoidal in aboral profile, the aboral surface is smooth or has a crest that may be forked at the base. Radial articular facets are flat (Fig. 2n) or inclined (Fig. 21); and muscle fossae are moderately high. First primibrachials are aborally rounded or with a weak crest, rather high and smooth; the distal facet is synostosial to cryptosynarthrial. Among the first primibrachials are symmetric (Fig. 2f) or asymmetric ossicles (Fig. 2g). Flat synostosial sides on first primibrachials indicate that they were in lateral contact (Fig. 2k). Second, axillary primibrachials may be smooth or have a crest on the aboral side (Fig. 2h). The ridge separating the distal muscular facets may be prolonged adorally, and the extension may be straight or directed sideways (Fig. 2h). The number of axillary second primibrachials with a proximal muscular facet indicates that the arms branched a second time. Proximal secundibrachials are wide and mostly rounded aborally (Fig. 2a-b). More distal secundibrachials have an aboral nipple or a low crest (Fig. 2c-e, i). Pinnule sockets are prominent (Fig. 2a-c). Synostoses or cryptosyzgies are numerous (Fig. 2d-e), including some symmorphies with cryptosyzygial facet (Fig. 2e). Figure $2 \mathrm{~m}$ shows a first primibrachial fused with a non-axillary second primibrachial that carries a pinnule socket; the pair is articulated with neighbouring ossicles by a flat synostosis with weak ridges.

Remarks. This species is easily recognised by its pentagonal column with sharp edges. Compared with $B$. gracilis and $B$. brachiospina $\mathrm{n}$. sp. fossulae seem to be rare. Some characters of radials and primibrachials, such as a smooth aboral surface or one with a crest, occur in pentagonalis and brachiospina, although the radial articular facet is more developed and steeper in the latter species. However, the arms of $B$. brachiospina carry a row of prominent thorns.

Balanocrinus subteres (MüNSTER in GOLDFUSS, 1831), Figs. 3a-c, 4.

1831 Pentacrinites subteres MüNSTER in GoldFuss 1826-1833, p. 176.

1867 Pentacrinus argoviensis MoEsch, p. 136, 138; pl. 7, fig. 10 .

1876 Pentacrinus subteres GoldFuss, Quenstedt, p. 245; pl. 99, fig. 26-55.

1879 Balanocrinus subteres (MÜNSTER), Loriol, p. 172, pl. 17, fig. 19-37.

1879 Balanocrinus argoviensis (MoESCH), Loriol, p. 180, pl. 17 , fig. $46-47$.

1887 Balanocrinus argoviensis (MOESCH), Loriol, p. 364; pl. 195, fig. 1-4.

1975 Balanocrinus subteres (MüNSTER), Hess, p. 58, p. 7, fig. 2, 6; pl. 20, fig. 8; pl.24, fig. 2-3.

$1979 \mathrm{~b}$ Balanocrinus subteres (MüNSTER in GoldFuss), Klikushin, p. 91; fig. 2c-d, 3c.

1982 Balanocrinus subteres (MüNSTER in GOLDFUSS), Klikushin, p. 302, pl. 2, fig. 6.

1992 Balanocrinus subteres (MüNSTER in GoldFuss), Klikushin, p. 87; pl. 5, fig. 9-12. 


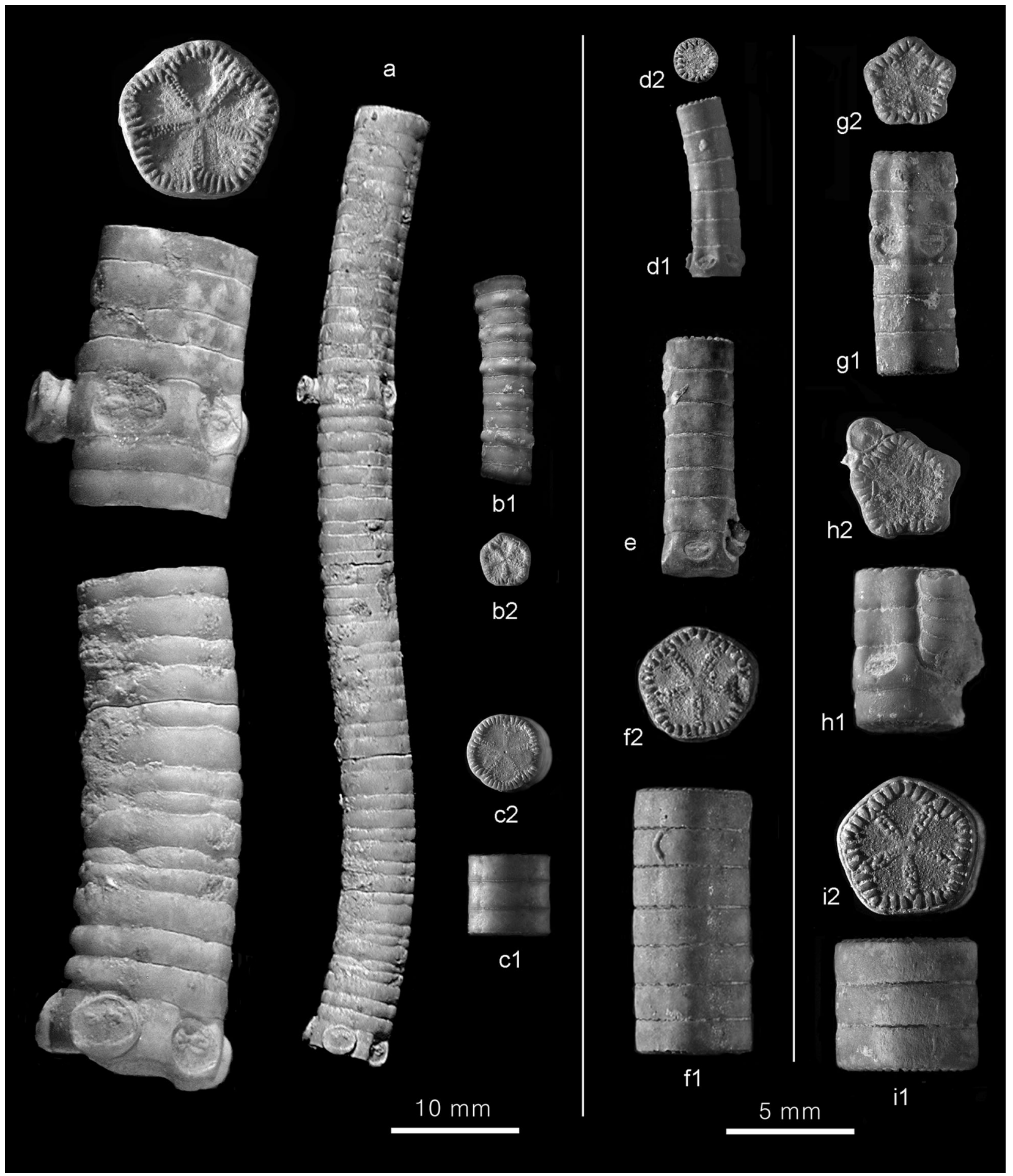

Fig. 3 Size and morphological features of Oxfordian Balanocrinus columns. Balanocrinus subteres (MÜNSTER in GoldFuss); Birmenstorf Member, Middle Oxfordian (Transversarium Zone), Chalch Quarry, Holderbank. $a$ Pluricolumnal with complete noditaxis (enlarged parts at left), M11338, note lack of cupules and cirri sticking out laterally. $b$ Pluricolumnal with characters of B. argoviensis (MoEsCH), M11344, $b 1$ lateral, $b 2$ lower facet. $c$ Pluricolumnal of 3 internodals, M11355, c1 lateral, c2 upper facet. Balanocrinus brachiospina n. sp., early Late Oxfordian, Savigna. $d$ Pluricolumnal of 6 with nodal at base, M11341, $d 1$ lateral, $d 2$ upper facet. $e$ Pluricolumnal of 7 with nodal at base, M11340, note cupules for reception of the proximal part of the cirri. $f$ Pluricolumnal of 7 internodals, this is the largest column from Savigna, M11339, $f 1$ lateral, $f 2$ upper facet. Balanocrinus brachiospina n. sp., Early Oxfordian, Andelot-Morval. $g$ Pluricolumnal with nodal, 11356, $g 1$ lateral, $g 2$ upper facet. $h$ Pluricolumnal with nodal and adpressed cirrus, M11357, $h 1$ lateral, $h 2$ upper facet. $i$ Large pluricolumnal of 3 internodals, M11358, i1 lateral, i2 upper facet 


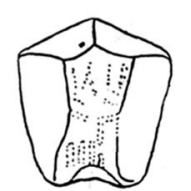

a

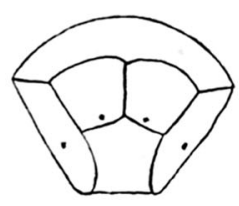

b

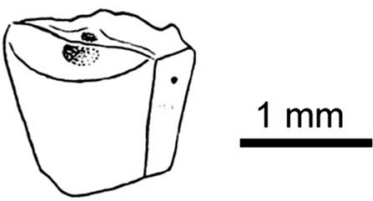

C

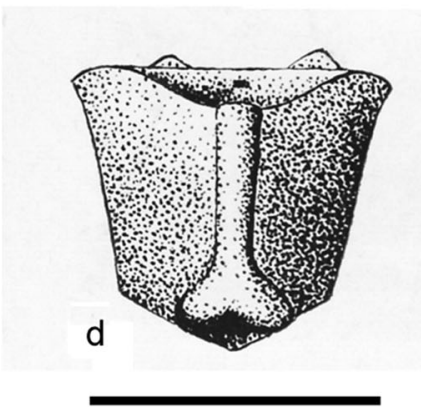

e1

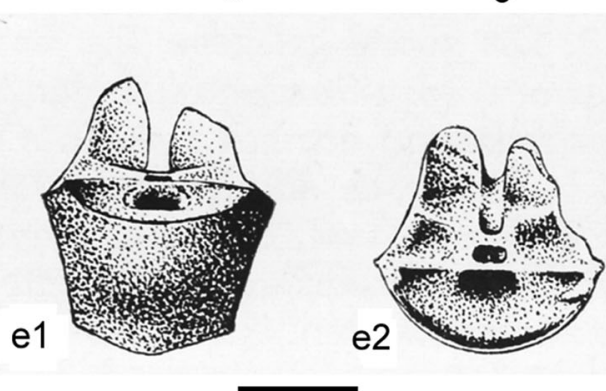

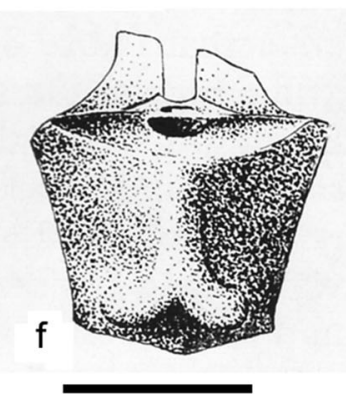

Fig. 4 Balanocrinus subteres (MüNSTER in GoldFuss), basal Impressamergel Formation, Middle Oxfordian (Transversarium Zone), Heldenberg near Winzingen (Swabian Alb), from Sieverts-Doreck (1967). a Adoral view of basal, SMNS 69390/1. b Proximal view of radial, note facets to basals, SMNS 69390/2. c Oblique aboral-distal-

1996 Balanocrinus subteres (MÜNSTER in GolDFuss), Klikushin, p. 118, pl. 8, fig. 7-10.

2011 Balanocrinus subteres (MüNSTER in GoLDFuss), Hess and Messing, p. 56, fig. 301a-c.

Material. Pluricolumnals from the Middle Oxfordian Birmenstorf Member of the Chalch Quarry, Holderbank, Switzerland (see Hess and Spichiger 2001), include a complete noditaxis and two pluricolumnals with characters of B. argoviensis (MoEsch). Sieverts-Doreck (1967) described cup plates from the Middle Oxfordian (Transversarium Zone) basal Impressamergel Formation of the Swabian Alb that are reproduced herein.

Diagnosis. Large Balanocrinus. Column cylindrical, rarely pentalobate, smooth; columnals rather low, may be unequal in height and slightly convex. At least 41 columnals per noditaxis. Nodals somewhat larger than internodals, cirrus sockets large, oval to nearly circular and directed outwards, cupules lacking. Cirral scar width $40-50 \%$ of nodal diameter. Columnal facets with short and uniform marginal crenulae that diminish towards smooth margin so that sutures appear straight from the outside; narrow radial ribbons of small, mostly paired crenulae that may be irregular. Fossulae poorly developed. Basals high, forming closed circlet. Radials trapezoidal in outline, aborally smooth or with forked crest; articular facets with high muscle fossae. Primibrachials and secundibrachials unknown.

Description. Long pluricolumnals with complete noditaxes are exceptional finds in this species. The longest pluricolumnals without nodal recorded by Loriol $(1879$, p. 174; 1887, p. 351) have 32 and 17 internodals, respectively. A lateral view of radial, SMNS 69390/3. Radials. d Aboral view of small, thin radial with forked crest, SMNS 69390/4. e Thick radial with smooth surface, SMNS 69390/5, e1 aboral, e2 distal articular facet. f Aboral view of radial with forked crest, SMNS 69390/6. Scale bars $1 \mathrm{~mm}$

non-figured specimen from Chalch of Holderbank from the Basel collection has at least 41 internodals; the well-preserved pluricolumnal in Fig. 3 a has 40 internodals, corresponding to a noditaxis of 41 . In this specimen the columnals are unequal in height, and they are partly swollen and irregular. However, most pluricolumnals are perfectly cylindrical (Fig. 3c) and, thus, typical of the species. The cirrus sockets occupy a large part of the latus, and cupules are lacking. The cirri are directed outwards. Basals and radials were described by Sieverts-Doreck (1967) and are reproduced in Fig. 4. The basals are high, indicating a closed circlet similar to B. brachiospina n. sp. The radials have a smooth aboral surface or a median, forked crest. The muscle fossae are rather high. While the radials are comparable in $B$. subteres, $B$. pentagonalis and $B$. brachiospina $\mathrm{n}$. sp., the column of the three species offers distinguishing features.

Remarks. The specimens figured by Loriol (1887; pl. 192, fig. 7-12; pl. 193) mirror the range of cylindrical columnals previously assigned to $B$. subteres because of a lack of cup plates and brachials. For example, a specimen (Loriol, pl. 193, fig. 17) is from the Bathonian of La Clapouze, where other species of Balanocrinus occur (see Hess 2012). However, the small pluricolumnals and the pluricirral from Chatelneuf (Loriol, pl. 193, fig. 22-25) may well belong to B. brachiospina $\mathrm{n}$. sp. described in the following; one of the specimens has a distinct cupule (pl. 193, fig. 24a), and the cirrus (pl. 193, fig. 25a) is also similar to that of $\mathrm{B}$. brachiospina n. sp. The majority of columns of the species is composed of smooth, cylindrical columnals but some specimens have slightly convex columnals that may be 
unequal in height or swollen at midline. Such a pluricolumnal was figured by Quenstedt (1876, pl. 99, fig. 38) from the Plettenberg locality and assigned to B. subteres. Balanocrinus argoviensis (MoEsch 1867) from the Middle Oxfordian is based on four specimens from Birmensdorf (now Birmenstorf); it was diagnosed as having a knob or pustule at the interradial edge of every second columnal. Moesch's figure (pl. 7, fig. 10) shows a more or less distinct median ridge on the latera between the knobs. Loriol's figures (1879, pl. 17, fig. 46-47) of specimens in the Zürich collection show a pentalobate column with ridges interrupted by distinct radial furrows. Unfortunately, Moesch's original cannot be traced any more in the Moesch collection of the Polytechnic High School in Zürich (M. Pika-Biolzi personal communication, 2012). However, two specimens from the Chalch Quarry of Holderbank in the Basel Museum have the same characters, although somewhat less produced. The better-preserved specimen (M11344) is figured in Fig. 3b. Loriol (1887, pl. 185, fig. 1-4) attributed additional specimens from the "Faciès à Scyphies" and "Couches d'Effingen" of eastern France to the species. The figured specimens are somewhat variable, with knobs or ridges on the latera, which may also be nearly smooth. Thus, $B$. argoviensis may be merely a phenotype of $B$. subteres. Salamon (2009) placed a subpentagonal columnal, a juvenile columnal, a secundibrachial and two cirrals from the Valanginian of epicratonic Poland in B. subteres. Circular columnals, secundibrachials and cirrals from the same locality were assigned to B. gillieroni LORIOL (1879). Based on a statistical comparison of columnal diameter versus height Salamon suggested that the two forms are conspecific. The paper is a good illustration of the taxonomic problems with such material. Loriol based B. gillieroni on two cylindrical pluricolumnals with a facet closely resembling that of $B$. subteres. In Loriol's original figure of $B$. gillieroni (1879, pl.18, fig. 3a) the sutures are distinctly crenulated in side view as a result of crenulae reaching the margin, although he writes on p. 183 "Les sutures linéaires, non enfoncées, laissent à peine apercevoir les denticulations". Rasmussen's (1961) diagnosis includes a crenulated suture, and this is also figured as such (pl. 9, fig. 3). The type specimen at the Basel Museum is a pluricolumnal of 6; the sutures are not well preserved but seem to be straight at least partly, and the better preserved facet has narrow ribbons of adradial crenulae resembling those of Salamon's $B$. gillieroni (Salamon 2009, fig. 3a). A subpentagonal pluricolumnal of 4 from the Valanginian of Censeau (Département Jura) at the Geneva Museum and mentioned by Loriol (1879, p. 184) has a facet resembling Salamon's B. subteres (Salamon 2009, fig. 3b), with the same arrangement of adradial crenulae. The sutures seem to be rather more crenulated than in the type specimen. In side view the columnal of Salamon's B. gillieroni (Salamon 2009, fig. 3c) seems to have more pronounced crenulae than his $B$. subteres (fig. 3d). Thus, the few specimens of Loriol's B. gillieroni mirror Salamon's material. The wide stratigraphical gap between $B$. subteres and $B$. gillieroni are in favour of the validity of the latter species, although the material is too meagre for a proper diagnosis.

Balanocrinus brachiospina n. sp., Figs. 3d-i, 5, 6, 7, 8, 9; see also Hess 2013a, fig. 3-4.

1887 Balanocrinus subteres (MÜNSTER), Loriol, p. 358; pl. 193, fig. 22-25.

1975 Balanocrinus sp., Zwergform von B. subteres (GoldFuss) and B. cf. subteres; Hess, pl. 20, fig. 1, 7; pl. 45, fig. 10-11.

1975 Balanocrinus subteres (GoldFuss); Hess, pl. 24, fig. 2-3.

Material. Savigna 2b. 61 single basals, one basal pair, 7 basal circlets; 228 radials; 168 first primibrachials; 187 axillary second primibrachials; 743 secondary axillaries (with muscular proximal facet). Secundibrachials are abundant, numbering some ten thousand, and some dozen arm fragments are also available. Pluricolumnals and single columnals (nodals and internodals) also number some ten thousand. For the number of postlarval, prejuvenile columnals see Hess (2013a). Savigna 1 furnished 12 radials, 20 first primibrachials, 13 second primibrachials, 41 axillary secondary brachials, several hundred secundibrachials, pluricolumnals and columnals. At Andelot-Morval the species is rather rare, and this is especially true of ossicles from the crown. The material includes 3 radials, 7 first primibrachials, 4 second primibrachials, 4 secondary axillaries, 6 hyposynostosial secundibrachials, one episynostosial secundibrachial and 172 secundibrachials with muscular articulation on both facets. A dozen pinnulars are also available, but their number in fact is higher because they were incompleteley picked from the fine fraction. Columnals and pluricolumnals are rather common. There are 337 single columnals (including a tetramerous nodal) and 334 pluricolumnals of up to 12 elements; but a complete noditaxis is not preserved. Cirrals include 132 single pieces and 46 pluricirrals with up to 6 elements. Some pluricolumnals are figured in Fig. 3g-i, and a radial, a first primibrachial and some brachials in Fig. 9d-n; they all compare well with the corresponding material from Savigna.

Holotype. Arm fragment, Fig. 8q, M11302.

Paratypes. Pluricolumnal, Fig. 7a, M11277; basal circlet, Fig. 5k, M11256; radial, Fig. 5g, M11253; second primibrachial with attached first secundibrachial, Fig. 5c, M11249; nodal with infranodal, Fig. 6k, M11268. 

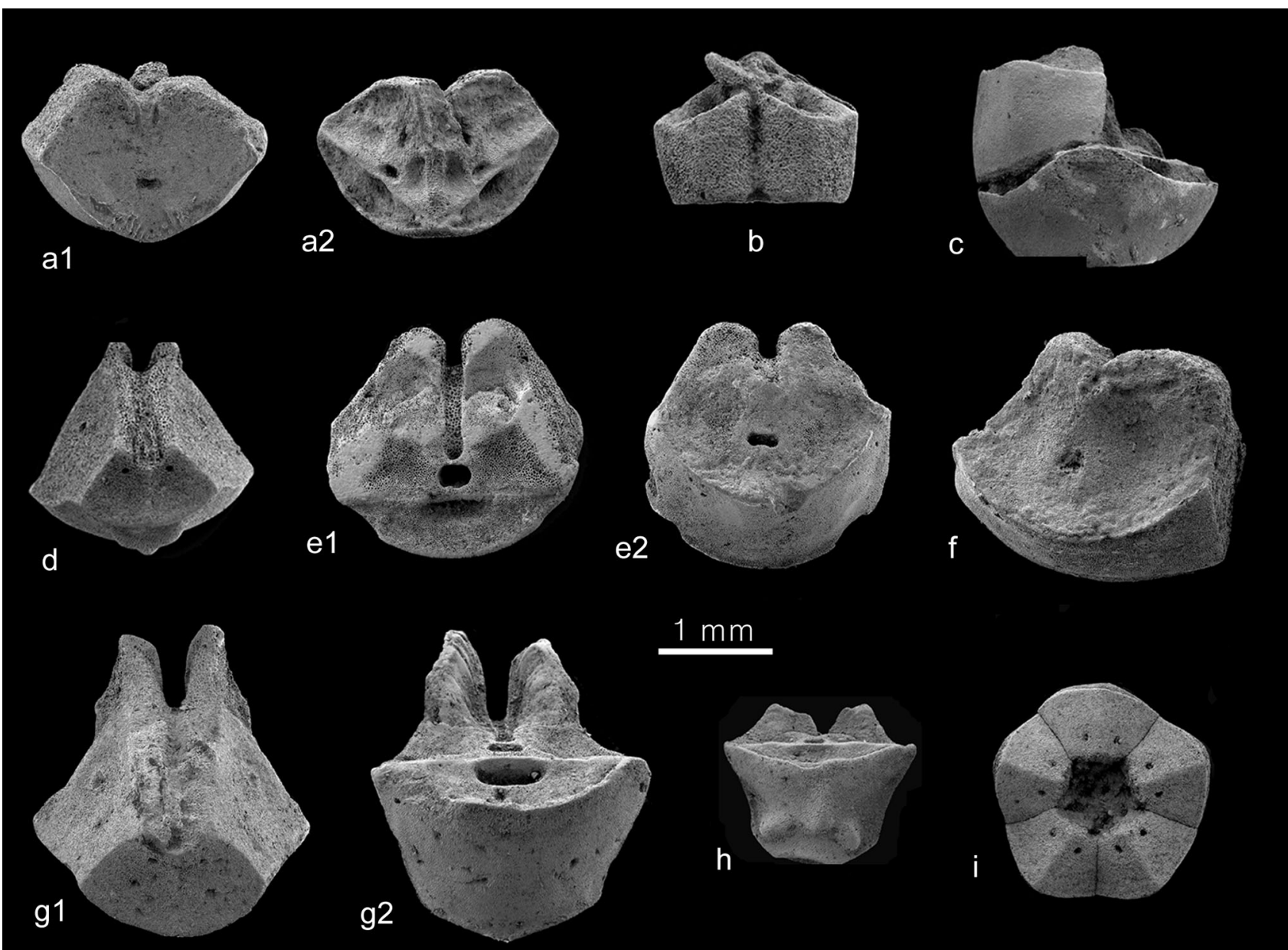

$1 \mathrm{~mm}$
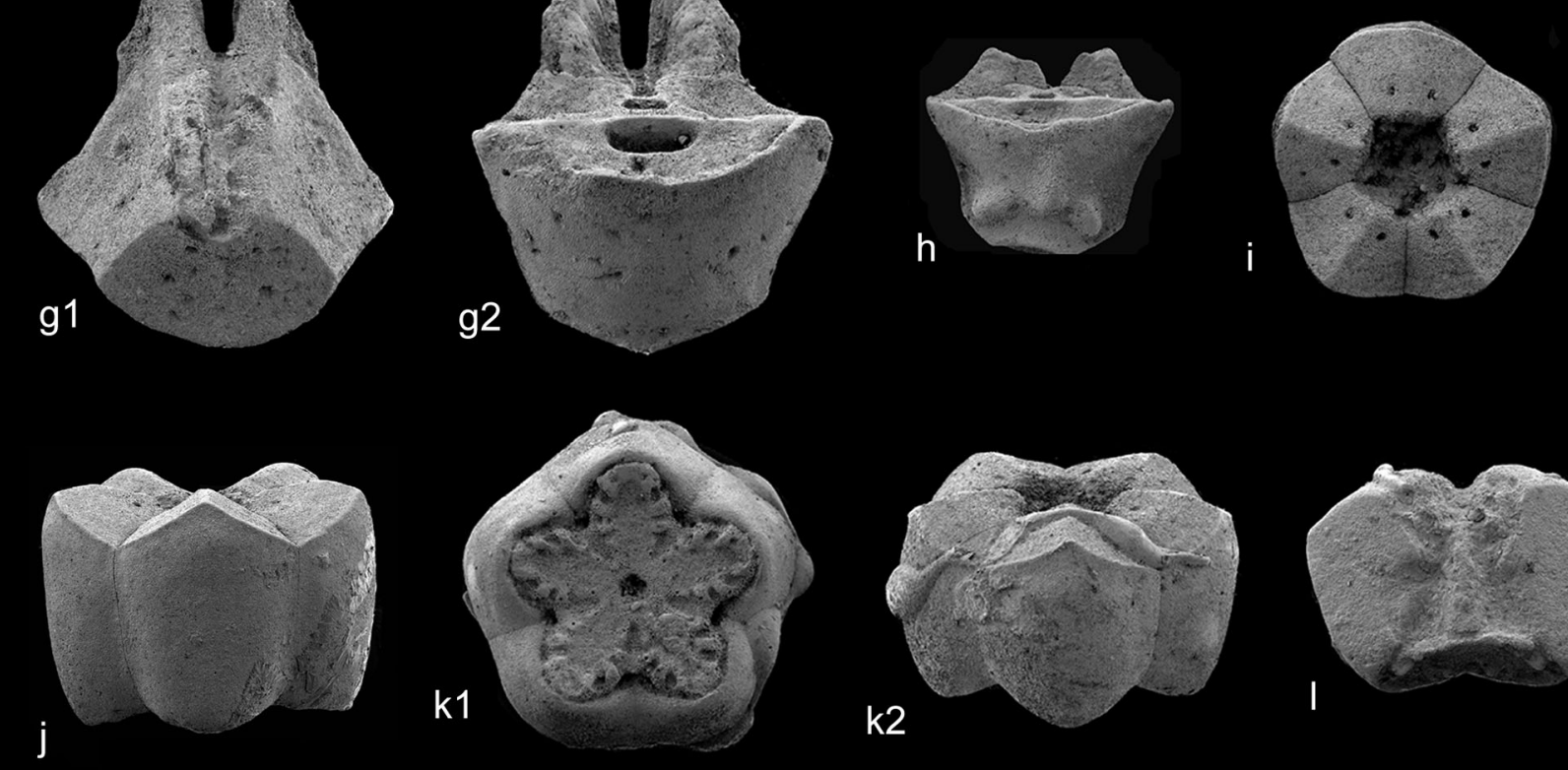

Fig. 5 Balanocrinus brachiospina n. sp., early Late Oxfordian, Savigna 2b. a Second primibrachial, M11247, a1 proximal, a2 distal. b Adoral view of second primibrachial, M11248. c Aboral view of second primibrachial and attached first secundibrachial with distal synostosial facet, M11249. d Proximal view of radial with low muscle fossae, note nerve canal on lateral synostosial facets, M11250. e Symmetric first primibrachial, M1251, e1 proximal, e2 distal, cryptosynarthrial facet. $\mathbf{f}$ Distal view of asymmetric first primibrachial

Etymology. From brachium, L, arm, and spina, L, thorn; after the thorned brachials.

Type locality and horizon. Savigna, $10 \mathrm{~km} \mathrm{SSW} \mathrm{of} \mathrm{Org-}$ elet, Département du Jura, France (see Gale 2011);

with cryptosynarthrial facet, M11252. g Radial with high scalloped muscle fossae, M11253, g1 adoral-proximal, g2 aboral-distal. h Aboral view of small radial with crest and knobs, muscle fossae low; M11254. i Distal (upper) view of basal circlet, note nerve canals, M11255. j Lateral view of high basal circlet, M11343. k Basal circlet of medium height, M11256, paratype, k1 proximal (lower) facet with first columnal, k2 oblique lateral-distal view with epizoic Nubeculina infraoolithica (TERQUEM). I Interior view of basal pair, M11257

Couches d'Effingen (Enay 1966), Stenocycloides Subzone of the Bifurcatus Zone, early Late Oxfordian.

Diagnosis. Small Balanocrinus. Basals high, forming contiguous circlet; aboral surface of radials smooth or with 
crest and paired knobs, muscle fossae high in adults; primibrachials united by cryptosynarthry or synostosis. First and second secundibrachials united by synostosis, numerous further synostoses and some symmorphies along arms; primibrachials and first secundibrachials commonly aborally rounded, following secundibrachials with crest developing along the arms into conspicuous thorn directed distally; arms divided at second primibrachial and further distally; proximal secundibrachials commonly skew, may meet laterally with flattened sides. Column cylindrical with high columnals, pentalobate proximally, proximal column with columnals alternating in thickness and with convex latus; at least 14 columnals per noditaxis; cupule on one or two supranodals; facet of internodals with strong marginal crenulae, ribbons of adradial crenulae weak in juvenile individuals to moderate in adults; nodals slightly larger than internodals, with stellate to pentalobate proximal facet; cirrus sockets oval, approximately half as high as nodal, directed upwards; cirral scar width $35-37 \%$ of nodal diameter; proximal cirrals oval to circular, increasingly long distally with irregular adoral crest, terminal claw more or less produced.

Description. The basals are high and form a contiguous circlet; they are connected by tight synostosis. The height/ width ratio of the basals is 1 , or more. The basal cavity is widened on top (Fig. 5i), then narrows and widens again near the concave base for reception of the first columnal (Fig. 5k1,1); a central plug indicates the course of the axial canal (Fig. 5l). The height of the radials is similar to that of the basals; large radials are aborally rounded and smooth (Figs. 5g, 911), and small ones have a crest with two knobs (Fig. 5h). The radials are connected by flat synostosial facets; at the centre of the resulting radial circlet is a more or less cylindrical adoral furrow, constituting the radial cavity as extension of the basal cavity (Fig. 5d, g1). The radial articular facet has a distinct, broad aboral pit, and the muscle fossae vary from high in adults (Figs. $5 \mathrm{~g}, 91$ ), where they are scalloped, to rather low (Fig. 5h) in smaller radials. The first primibrachials are mostly symmetric and aborally rounded, but may be more or less asymmetric (Fig. 5f); articulation between the primibrachials is flat synostosial (Fig. 5a1) or cryptosynarthrial (Figs. 5e2, f, 9k2). The second, axillary primibrachials are aborally rounded and may vary in height (Fig. 5b, c), but they are always higher than axillary secundibrachials. The arms branch a second time after the second primibrachial (Fig. 8p), and probably once more, as suggested by the 743 secondary axillaries with proximal muscular facet. In theory, the 187 second primibrachials at Savigna $2 \mathrm{~b}$ would give 374 axillaries with one additional branching but 748 with two; and this number closely matches the $743 \mathrm{sec}-$ ondary axillaries counted. Arm articulations include
Fig. 6 Balanocrinus brachiospina n. sp., early Late Oxfordian, Savigna $2 \mathrm{~b}$ (except $\mathrm{k}=$ Savigna 1 ). a Lateral view of pentalobate nodal with infranodal attached, M11258. b Proximal (upper) view of pentalobate nodal, M11259. c Proximal view of proximal nodal with interradial extensions and three cirrals, M11260. d Lateral view of juvenile nodal, M11261. e Proximal view of juvenile pentagonal nodal, M11262. f Proximal pluricolumnal with three internodals (two with inflated latus) and nodal with cirrals, M11263. g Oblique lateralproximal view of nodal with infranodal, M11264. h Oblique distallateral view of pentalobate pluricolumnal from proximal column with nodal on top, M11265. i Proximal column of low internodals with more or less inflated latus and three knobby nodals, M11266. j Proximal view of nodal with cirrals, M11267. k Nodal with infranodal, M11268, k1 lateral, k2 proximal. I Proximal pluricolumnal of internodals with fossulae, M11269, 11 upper facet, $\mathbf{2}$ lateral, note radial pores. $\mathbf{m}$ Proximal facet of nodal with fossulae, M11270. n Facet of subpentalobate internodal, M11271. o Facet of subpentalobate internodal with fossulae, M11272. p Facet of subcircular internodal, M11273. q Facet of tetramerous internodal, M11274. r Facet of large circular internodal, M11275. s Lateral view of possibly terminal internodal with Nubeculina infraoolithica (TERQUEM), axial canal sealed on lower side by hemispheric stereom growth, M11276

numerous synostoses (Figs. 8a-d, $9 \mathrm{~g}-\mathrm{i}$ ), the first is between the first and second secundibrachials (Fig. 5c). A number of brachials are weakly symmorphial, with fine marginal ridges (Figs. 8b, 9h). Proximal secundibrachials commonly are asymmetric or skew (Figs. 8d-h, 9i). Straight sides with ridges and grooves on some brachials indicate that neighbouring arms were in contact (Fig. 8m). Similarly asymmetric proximal secundibrachials of the extant Endoxocrinus (Diplocrinus) wyvillethomsoni (JEFFRIES) were figured by Carpenter (1884, pl. 21, fig. 3-4); but in this genus the second secundibrachial is axillary, and the arms may branch again at the second tertibrachial (see Hess and Messing, fig. 35,2a for Endoxocrinus (Diplocrinus) maclareanus [THOMSON]), resulting in rather crowded conditions in the lower part of the crown. In contrast, the second arm branching seems to occur later in B. brachiospina $\mathrm{n}$. sp. (see Fig. 8p) so that the presence of so many asymmetric or skew secundibrachials is surprising and quite exceptional in a fossil isocrinid. While proximal secundibrachials tend to be aborally rounded (Figs. $8 \mathrm{e}-\mathrm{g}, 9 \mathrm{~m}-\mathrm{n}$ ) some have one (Fig. 8d, h) or two (Fig. 8c) short processes. Crests (Fig. 8n) develop into the characteristic thorns of the majority of secundibrachials (Figs. 8i-1, o-s, 9d-f); twin thorns occur rarely in such brachials (Figs. 8k, 9b). In axillaries, the thorns are directed to one side (Fig. 81, p). Muscular facets of the brachials are mostly oblique, and all parts of the facets are distinct: aboral ligament fossa with pit, transverse ridge with axial canal, interarticular ligament fossae and adoral muscle fossae; the pinnule socket is pronounced (Figs. 8e, f2, i, k, 9d-e, j, m-n). Pinnulars are aborally keeled, and the proximal ones are asymmetric (Fig. 8t, v) and the following ones symmetric. The food 


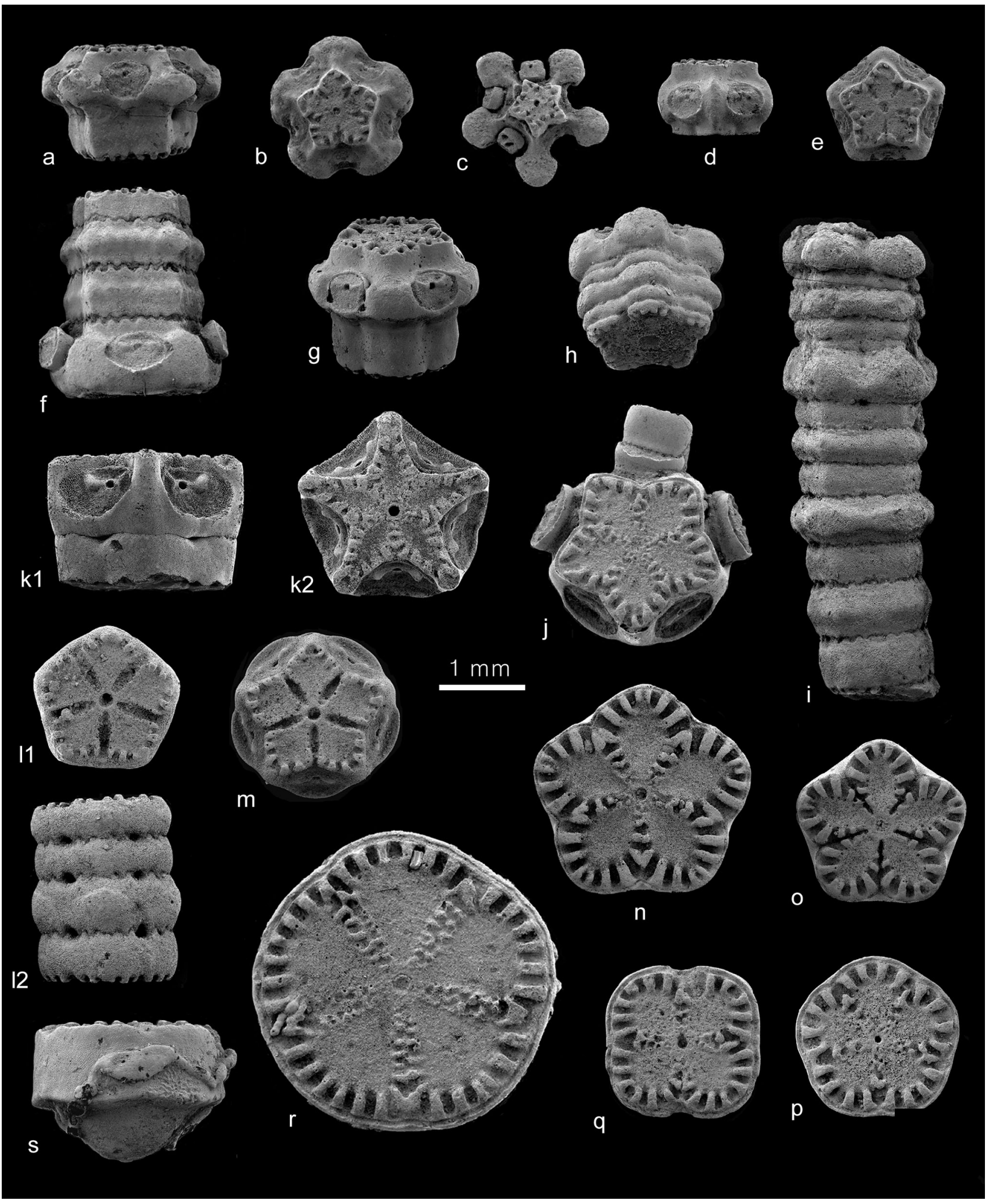

groove is lined with scars, suggesting the presence of cover plates (Fig. 8u). The majority of columnals is small and cylindrical. The largest pluricolumnal of 7 internodals has a diameter of $4.6 \mathrm{~mm}$ and a total height of $13 \mathrm{~mm}$ so that individual columnals are rather low (Fig. 3f). Smaller columnals tend to be relatively higher (Fig. 3d). Columns 


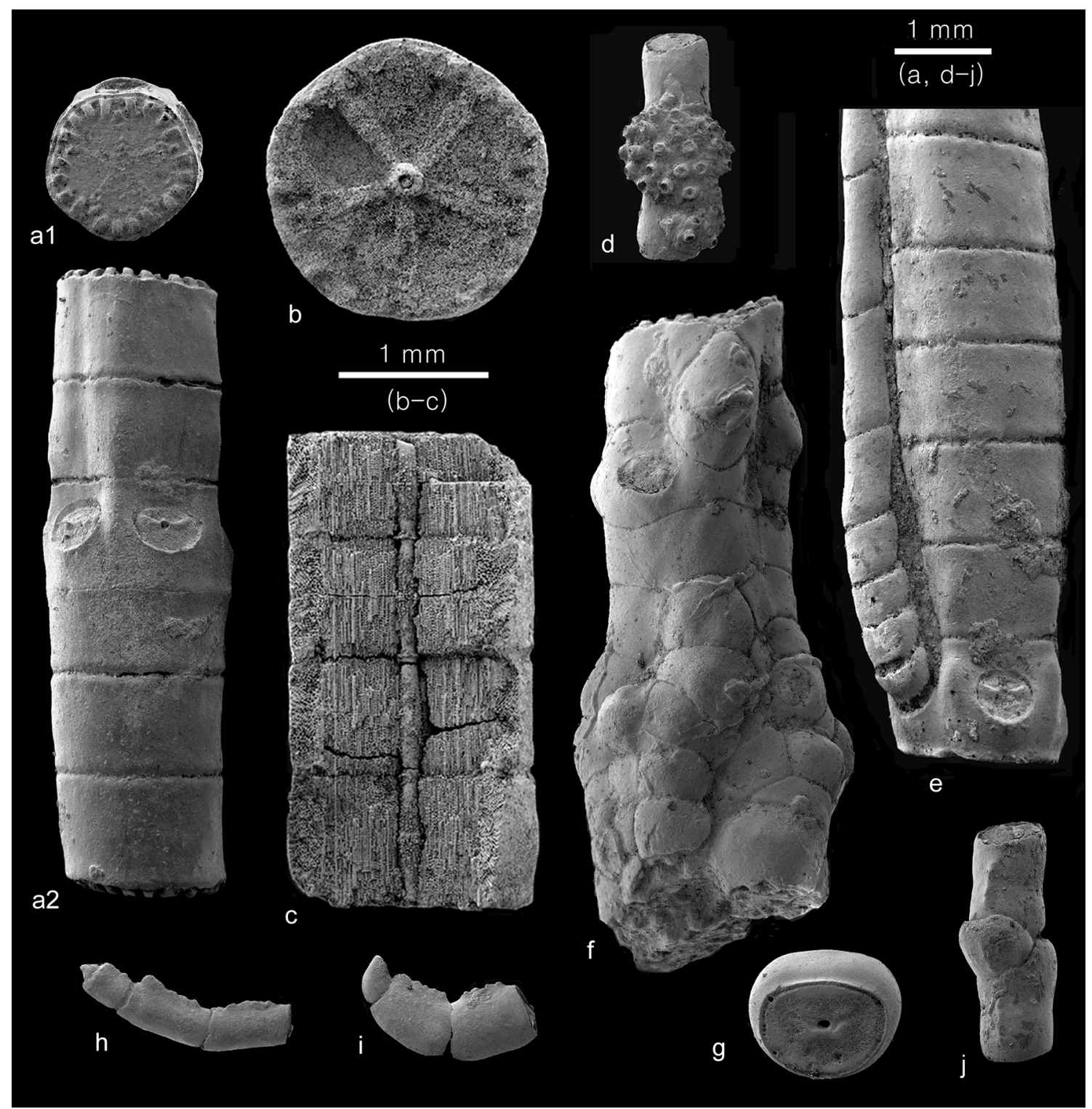

Fig. 7 Balanocrinus brachiospina n. sp., early Late Oxfordian, Savigna. a Pluricolumnal with nodal, M11277, a1 proximal (upper) facet, a2 lateral. b Facet of weathered internodal with galleried $\alpha$ stereom in the area of the interradial areolae and labyrinthic $\beta$ stereom along the radii and margin, M11278. c Broken pluricolumnal showing axial cross-section in the area of the areolae with throughgoing ligaments $(\alpha$-stereom) and labyrinthic $\beta$-stereom around the latus, the lumen of the axial canal is filled by sediment, M11279.

from Andelot (Fig. 3g-i) compare well with those from Savigna. In a prejuvenile pluricolumnal of 4 with nodal and a total height of $2 \mathrm{~mm}$ the internodals with symplectial facets have a diameter of $0.4 \mathrm{~mm}$ and the nodal one of $0.6 \mathrm{~mm}$. Morphology of prejuvenile columnals is discussed in detail in the parallel paper (Hess 2013a, fig. 3). In the proximal part of the column the columnals are pentalobate, pentastellate or pentagonal in outline; they vary in thickness, and the latera are more or less inflated (Fig. 6h, i, l). d Pluricirral with epizoic bryozoan "Berenicea", M11280. e Pluricolumnal with cirrus, M11281. f Pathological pluricolumnal with stunted columnals and a nodal with only one cirrus socket, M11282. g Facet of proximal cirral, M11283. h Distal part of pluricirral with small terminal claw, M11284. i Distal part of pluricirral with higher cirrals and larger terminal claw, M11285. j Pluricirral with stunted element, M11363

The nodals are pentalobate to pentagonal in outline, with swollen interradii in pentalobate specimens (Fig. 6a-c, fi). The proximal facet of the nodals is more or less stellate as the result of well-developed cupules, and this is true for nodals from proximal or more distal parts of the column (Fig. 6b, c, e, k2, j). A small, juvenile nodal has extremely produced interradial lobes (Fig. 6c). Intercolumnal radial fossulae are common in the proximal part of the column (Fig. 6b, e, 1, m, o). These show up on the latera as radial 
pores (Fig. 612). However, they are only weak and disappear distally in other columns of similar size from the proximal part of the column (Fig. 6i). The internodals have symplectial facets with strong marginal crenulae that may be V-shaped and fused adradially (Fig. 6n, r). Adradial crenulae are ribbons of mostly two smaller, irregular or fused crenulae (Fig. 6p-r). They are poorly developed or lack altogether in proximal facets of small nodals (Fig. 6b c, e) or in columnals with fossulae (Fig. 611, m, o). Nodals and internodals from the median or distal part of the column corresponding in size have similar adradial crenulae (Fig. 6j, p).

Pathological specimens and epizoans Pathological specimens are rare. The most prominent example is a pluricolumnal composed in its lower part by stunted round columnals and a nodal with only one cirrus socket (Fig. 7f). A pluricirral with a stunted element (Fig. 7j) is exceptional, and such a case has not been previously observed in any crinoid by the author. Only three columnals with tetramerous facet have been found (Fig. 6q). On cirrals epizoic bryozoans (Fig. 7d) and serpulids are rather common; serpulid worms also occur on columnals (Hess 2013a, fig. 3c), cup plates and brachials. Bryozoans are referred to "Berenicea", an informal name; without the reproductive zooids (gonozooids) it is impossible to identify the genus (P. Taylor, personal communication 2012). Foraminifera on cup plates (Fig. 5k), columnals (Fig. 6s) and brachials are mostly Nubeculina infraoolithica (TERQUEM), see also Hess (1966, fig. 49) for a specimen on a ophiuroid lateral arm plate. The epizoans settled on disarticulated ossicles as indicated by overgrown cirrus sockets (Hess 2013a, fig. 3c) or the upper facet of a basal circlet (Fig. 5k2). However, pluricirrals overgrown and enclosed by bryozoans suggest that growth may also have occurred during life, possibly on cirri anchored to the bottom.

Remarks. The facets of cylindrical columnals of Balanocrinus found in Middle to Late Oxfordian mudstones of the French and Swiss Jura resemble those of Balanocrinus subteres from the Middle Oxfordian sponge facies of Germany and Switzerland. However, B. subteres is much larger, columnals tend to be slightly convex, or they may be unequal in height. The cirrus sockets occupy a larger part of the latus, cupules are lacking, and cirri are directed outwards (see Fig. 3). In contrast, basals and radials of $B$. subteres and B. brachiospina n. sp. are similar (see Figs. 4, 5). Another Oxfordian species with cylindrical column is B. stockhornensis LoRIOL (1879), but here the columnals are concave and the marginal crenulae are more produced. B. changarnieri LoRIol (1887) from the "Corallien" of eastern France (corresponding to the Liesberg Member in Switzerland) has columns not regularly cylindrical and generally low columnals. However, facets of internodals, cirrus sockets with cirri and cupules correspond to those of B. brachiospina $\mathrm{n}$. sp. The material described by Loriol (1887, p. 375) was based on 400 fragments, all of similar morphology and size. Thus, columnals from different parts of the column offering additional characters for comparison are not available in this species. B. privasensis LORIOL (1887) from the Oxfordian of Ardèche is characterised by a small pustule on the latus close to the suture.

Perhaps of more interest is a comparison of $B$. brachiospina n. sp. with Balanocrinus species where plates of cup and arms are known. The Lower Jurassic B. gracilis (Charlesworth), B. solenotis Simms and B. subteroides (QUENSTEDT) all have aborally rounded brachials throughout the arms, and the aboral facet of the radials is unornamented. Externally, the basals are barely in touch or separate in B. gracilis and B. solenotis (Simms 1989), but closed in B. subteroides (Sieverts-Doreck 1981). The basals of $B$. gracilis are triangular in outline and lower than in B. brachiospina n. sp. Simms (1989, p. 66) mentioned height/width ratios of about 0.5 in specimens of $B$. gracilis from England. In larger specimens from Sedan the ratio is similar (Hess 2013a, fig. 2f, g), but it increases to 1 in a juvenile individual (fig. 2e). Brachial articulations in $B$. gracilis may be cryptosyzygial (Simms 1989, pl. 11, fig. 16), and the two primibrachials of this species are articulated by an embayed synarthry (Simms 1989, pl. 11, fig. 8; Hess 2013a, fig. 2d). Radials and brachials of $B$. maritimus BouRsEAu et al. (1998) from the Upper Jurassic are aborally rounded. Brachial articulations are poorly known in this species, but the primibrachials are articulated by a synarthry. The basal circlet is closed, and basals have a height/width ratio of 0.75 (measured on the specimen of Bourseau et al., fig. 7, 2).

Subfamily Isocrininae Roux, 1981.

Isocrinus vON MEYER in AgAssiz, 1836.

Isocrinus munieri (LoRIOL, 1887), Fig. 10m-u.

1887 Pentacrinus munieri LoRIOL, p. 263; pl. 178, fig. 5.

Material. Most of the material is from Savigna 2b: 60 internodals, 15 nodals or infranodals. Most pluricolumnals are short: 16 of 2 ( 2 with nodal); two of 3 ; three of 4 (one with nodal); one each of 5, 6 and 8 (all without nodal). A number of cirrals belong here (Fig. 10s-u).

Description. The internodals are stellate, with acute interradial angles and latera ornamented by either knobby median ridges situated radially plus a single knob interradially, or by only an interradial knob (Fig. 10r). The facets between internodals and the proximal facet of nodals have narrow petals and strong crenulae. Fossulae are restricted to thin, probably postlarval proximal internodals with cryptosymplectial facet (Fig. 10o), and they lack in older, juvenile internodals (Fig. 10n). Nodals are stellate, similar 
to internodals (Fig. 10m, p). The cirrus sockets are oval, large, protruding and directed outwards, with a transverse ridge thickened at the ends (Fig. 10q). Cirrals are oval in profile, proximally short and becoming progressively longer distally (Fig. 10s-u). They are easily distinguished from the cirrals of $B$. brachiospina $\mathrm{n}$. sp. by their larger size and the sinuous, strongly synarthrial facets.

Remarks. The species was based on a single pluricolumnal with nodal. It was compared by Loriol with Isocrinus amblyscalaris (ThURMANN) (=Isocrinus pendulus voN MEYER, see Hess and Messing 2011, p. 50) but considered to be specifically different. A similar form is Pentacrinus pellati LoRIOL (1887, p. 162, pl. 178, fig. 4). It has very low columnals alternating with higher ones, and the latera are ornamented by ridges and knobs. Loriol's material was limited, and he did not compare pellati with munieri although the forms are very similar. Both species are of Middle Oxfordian age (pellati: Terrain à chailles; munieri: Zone à Cidaris florigemma, Corallien) and may well be conspecific.

Suborder Pentacrinitina GRAY, 1842.

Family Paracomatulidae Hess 1951.

Paracomatula Hess 1951.

Paracomatula morator n. sp., Fig. 11a.

Material. One centrodorsal.

Holotype. Centrodorsal, Fig. 11a, M11229.

Etymology. morator, L, struggler; this is the last stratigraphic occurrence of the genus, with a centrodorsal that may have lost the lower part on the way.

Type locality and horizon. Andelot-Morval (Département Jura, France); Early Oxfordian.

Diagnosis. Centrodorsal composed of closely united smaller upper and larger lower columnal; upper facet with irregularly crenulated interradial petals and moderately wide centrodorsal cavity, perilumen smooth; aboral facet of lower columnal with narrow interradial petals and strong crenulae that coalesce around the narrow centrodorsal cavity, which may have been sealed by one or more additional, not preserved columnals. Cirrus sockets as high as columnals, smaller on upper columnal, offset to either side of radial midline, sockets on lower columnal with marginal granules, but otherwise smooth.

Description. The specimen is composed of a smaller and a larger columnal. The outline is dominated by the larger columnal with blunt interradial tips. The interradial petals on the exposed lower facet are narrow and bordered by strong crenulae; the centrodorsal cavity or axial canal is
Fig. 8 Balanocrinus brachiospina n. sp., early Late Oxfordian, Savigna 2b. Secundibrachials, arm fragments and pinnulars. a Synostosial facet of high, asymmetric proximal brachial, note calcareous deposits, other facet muscular without pinnule socket, M11286. b Proximal, symmorphial facet, other side is muscular with pinnule socket, M11287. c Oblique view of distal, synostosial facet of skew brachial with twin thorns, proximal facet is muscular without pinnule socket, M11288. d Oblique view of proximal, synostosial facet of skew brachial with nipple, other facet is muscular with pinnule socket, M11289. e Distal, muscular facet of skew, aborally rounded brachial from proximal arm region with pinnule socket, other side is muscular, M11290. f Strongly asymmetric brachial from proximal arm region, M11291, f1 proximal facet, $\mathbf{f 2}$ oblique view of distal facet with pinnule socket. g Proximal facet of skew, asymmetric brachial, other side is synostosial (similar to d), M11292. h Proximal facet of extremely skew brachial, other facet is muscular with pinnule socket, M11293. i Distal facet of brachial with pinnule socket and long thorn, M11294. j Lateral view of brachial with thorn, pinnule socket at left, M11295. k Distal facet of brachial with pinnule socket and twin thorns, M11296. I Distal view of secondary axillary with thorn, other facet muscular, M11297. m Oblique adoral view of two proximal brachials joined by muscular facet, cirrus socket on lower brachial, straight sides with grooves indicate that arms were in contact laterally, synostosis at both ends; M11298. n Aboral view of two brachials with aboral keel and straight sides, joined by muscular facet, pinnule socket on lower (proximal) brachial, synostosis at both ends; M11299. o Aboral view of fragment of four brachials with thorn, all articulations muscular; M11300. p Aboral view of arm fragment with axillary (fifth brachial from below), all brachials with thorn, note synostosis on top (distal facet of tertibrachial 2); M11301. q Lateral view of arm fragment with thorned brachials and proximal pinnulars, holotype, M11302. r Lateral view of arm fragment with proximal pinnules, M11303. s Lateral view of three brachials, lowest brachial displaced, showing part of distal facet with exposed pinnule socket, M11304. t Oblique lateral-adoral-proximal view of pinnular, M11305. u Adoral view of pinnular with scars for cover plates, M11306. v Aboral view of proximal pinnular, M11342

surrounded by a ring of coalesced crenulae dominating the perilumen. The radial areas are smooth on both facets. The cirrus sockets are large, concave and offset to one side of the radial midline; they are smooth except for a ring of fine granules around the margin. The upper columnal is lower and somewhat irregular; the reduced outline may in part be due to some weathering of the interradial tips. The cirrus sockets are about half the size of that of the lower columnal. The centrodorsal cavity or axial canal is rather wide, and the perilumen is smooth. The interradial petals are wider than those on the aboral surface of the lower element, and the crenulae are less produced. The interpretation of the smaller columnal as upper, adoral part of a centrodorsal is based on the wider lumen of the axial canal assumed to be the centrodorsal cavity. The weakly sculptured facet seems well suited to the reception of a basal circlet.

Remarks. The specimen may at first sight seem to be part of a column of a Pentacrinites species. However, the unequal size of the apparently fused columnals, the probable lack of an internodal, facets with strongly crenulated 


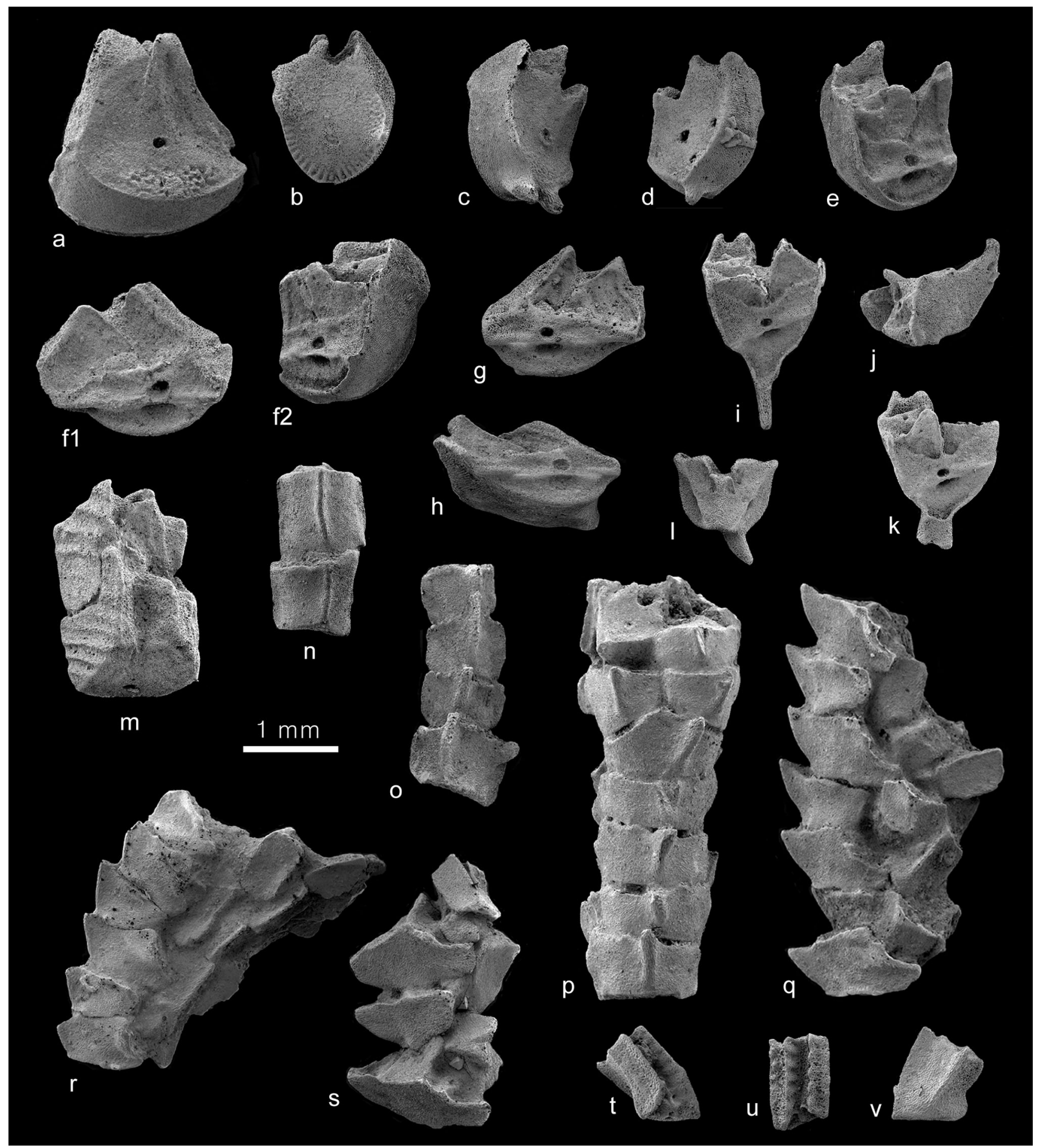

interradial areas and wide axial canal (seemingly a centrodorsal cavity) do not favour such an interpretation. There is no set of columnals among Isocrinida with such characters. The adoral facet (Fig. 11a3) with its irregular, crenulated interradial petals resembles that of the presumed paracomatulid Singillatimetra inordinata Hess (2012, fig. 10a3). This Bathonian species seems to lack a centrodorsal cavity, but this may have been obscured by filling with sediment or secondary stereom. In comparison with Paracomatula helvetica Hess (1951) from the Bajocian and P. liasica Hess (2006) from the Pliensbachian, the present centrodorsal has a much wider axial canal, interpreted as centrodorsal cavity, and the interradial crenulae are produced more. 


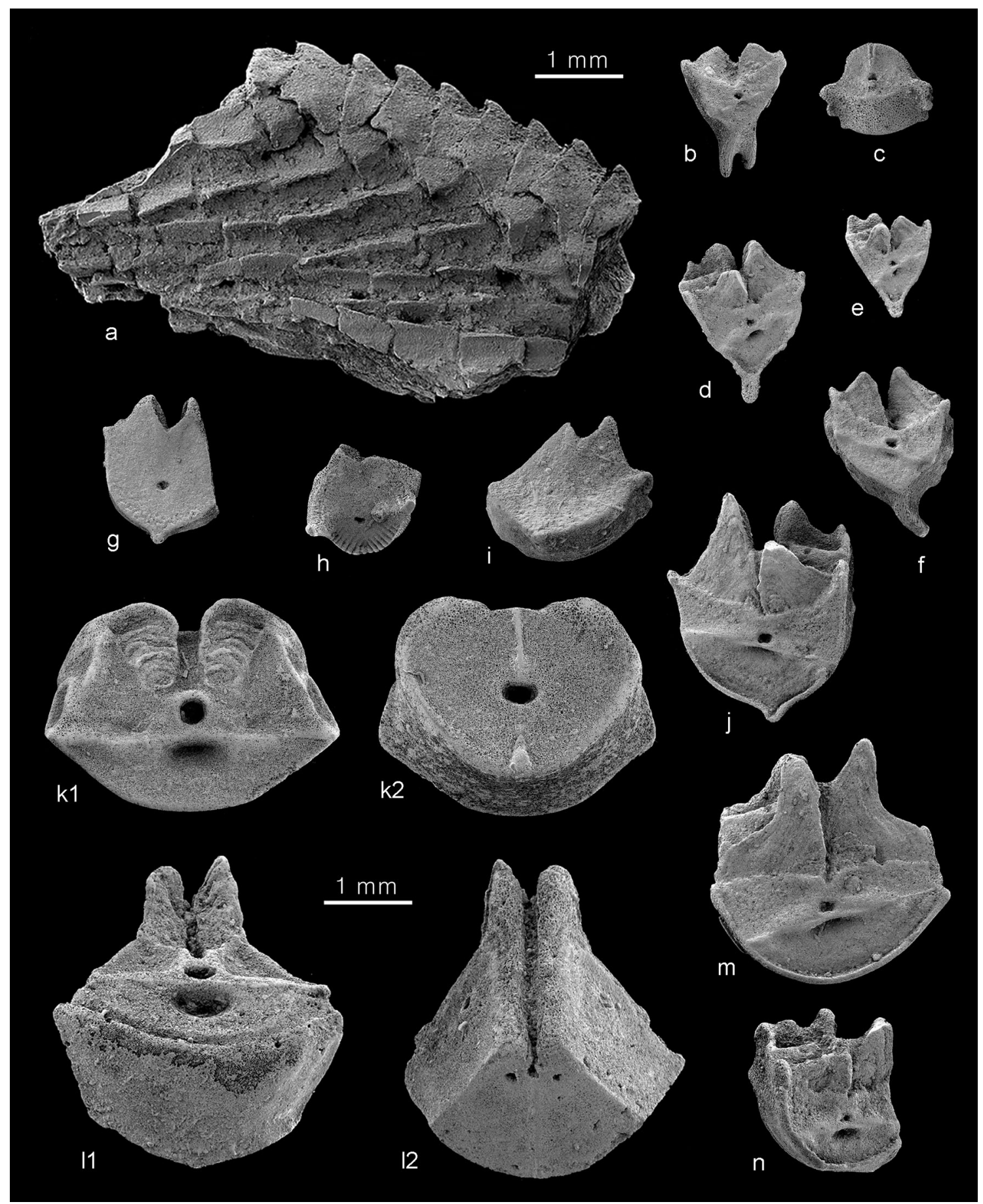

Fig. 9 Balanocrinus brachiospina $n$. sp. early Late Oxfordian, Savigna $(\mathbf{a}-\mathbf{c})$ and Early Oxfordian, Andelot-Morval (d-n). a Part of median arm with pinnules, M11369; this specimen is from the locality Petit Buis at the top of the Savigna outcrop. b Proximal facet of secundibrachial with twin thorns, M11370. c Distal, cryptosynarthrial facet of first primibrachial with lateral lappets, M11371. d Distal facet of secundibrachial with pinnule socket, M11372. e Distal facet of secundibrachial from distal part of arm with pinnule socket, M11373. f Proximal facet of secundibrachial with curved thorn, M11374. g Distal facet of hyposynostosial secundibrachial, other facet is muscular without pinnule socket, the straight side suggests that brachial is from proximal part of arm, M11375. h Proximal, cryptosyzygial facet of episymmorphial secundibrachial, other side is muscular with pinnule socket, M11376. i Distal facet of skew hyposynostosial secundibrachial, M11377. j Distal facet of large secundibrachial with pinnule socket and nipple, M11378. k First primibrachial, M11379, k1 proximal facet, note scalloped muscle fossae, $\mathbf{k} 2$ distal, cryptosynarthrial facet. 1 Radial, M11380, 11 distal-aboral view, note narrow, scalloped muscle fossae, $\mathbf{1 2}$ proximal-adoral view, note nerve canals to basals and to neighbouring radials. $\mathbf{m}$ Distal facet of secundibrachial with pinnule socket, lack of thorn and large size indicate position in proximal part of arm, M11381. n Distal facet of skew secundibrachial with pinnule socket, lack of thorn suggests position in proximal part of arm, note resemblance to e; M11382 
Order Comatulida A. H. Clark, 1908.

Superfamily Solanocrinitoidea JAEKEL, 1918.

Family Solanocrinitidae JAEKEL, 1918.

Palaeocomaster GISLÉN 1924.

Palaeocomaster musculosus n. sp., Figs. 14c, 15a-b.

Material. From Savigna: one cup without centrodorsal and one centrodorsal; from Andelot: two centrodorsals, the centrodorsal not figured has a diameter of $1.4 \mathrm{~mm}$. Three radials from Savigna (Fig. 13a-c) are also assigned to this species.

Holotype. Cup, Fig. 12a, M11226.

Paratype. Centrodorsal, Fig. 12b, M11227.

Etymology. musculosus, L, for the large muscle fossae on the radial articular facet.

Type locality and horizon. Savigna, $10 \mathrm{~km} \mathrm{SSW} \mathrm{of} \mathrm{Org-}$ elet, Département du Jura, France (see Gale 2011); Couches d'Effingen (Enay 1966), Stenocycloides Subzone of the Bifurcatus Zone, early Late Oxfordian.

Diagnosis. Small species. Centrodorsal five-sided, with protruding interradial fingers that may represent basals; cavity $20-30 \%$ of centrodorsal diameter, adoral side shows imprint of narrow basals with crenulated rim extending to centrodorsal cavity, but basal circlet may also be fused with centrodorsal; cirrus sockets circular and nearly smooth, in two irregular rows, some upper sockets much smaller than the lower ones; aboral apex flat, surface rugose to nearly smooth. Radial circlet high, pentagonal in outline; adoral side seemingly with embedded basal circlet of narrow and concave interradial extensions and crenulated rim united centrally around cavity, hardly visible from outside. Aboral surface of radials not exposed, overhanging; radials with high, steep facets meeting interradially in distinct furrow; interarticular ligament fossae triangular, adoral muscle fossae high and separated by moderately deep median notch; radial cavity moderately wide.

Description. The centrodorsal from the type locality (Fig. 12b) is very small, irregulary five-sided with fingerlike interradial projections that are prominent on the upper (adoral) surface; they may be part of the basal circlet fused with the centrodorsal. The adoral surface is somewhat weathered and has a cavity with a diameter of nearly $30 \%$ of centrodorsal diameter. There are two rows of mostly large and circular cirrus sockets, offset against each other; a few sockets near the upper edge are much smaller. The sockets are mostly smooth, but some are bordered by fine crenulae. The sockets seem loosely assembled, and their bases may be recognised on the aboral side as rugosities. The centrodorsal from Andelot (Fig. 11c) is better preserved and shares the main characters with the Savigna specimen. With $22 \%$ of centrodorsal diameter the centrodorsal cavity is narrower than the Savigna specimen. The adoral surface displays finger-like interradial projections with crenulated rims that connect around the cavity, and this structure may indeed represent a basal circlet. In each radial area is a tube leading to a small, nascent cirrus socket. Development of cirrus sockets is similar to the Savigna specimen. The aboral side is rather flat, but has lanceolate to circular interradial elevations radiating from a faint central knob, and the elevations are rimmed by small crenulae. The cup (Fig. 12a) is high, pentagonal in outline, with a flat to slightly concave base. On the proximal side are narrow, centrally united and concave rods that are embedded in the radial circlet. Their margin is produced as narrow, crenulated rim that also surrounds the central cavity. This structure may be interpreted as a basal circlet, but it may also be the imprint of the basal circlet prominently displayed on the centrodorsal. The radials meet laterally in a distinct furrow. Their aboral side is overhanging and not visible from the side; the lateral view is dominated by high facets, about half of which are muscle fossae, scalloped in the upper part. The axial canal is surrounded by a rim extending to the transverse ridge and framing the triangular interarticular ligament fossae. Three isolated radials (Fig. 10a-c) seem to belong to this species. Their high muscle fossae are similarly scalloped as in the holotype.

Remarks. The present species is distinguished from the Bathonian Palaeocomaster messingi Hess (2012) by a higher centrodorsal with cirrus sockets unequal in size and a higher radial circlet with larger muscle fossae; the centrodorsal cavity is wider. The other species of the genus, all from the Bathonian, $P$. schlumbergeri (LoRIOL), P. stellatus CARPEnTER, and $P$. latiradius (CARPENTER) have lower radial facets and muscle fossae (see also Gislén 1924, p. 143; Hess 2013b, fig. 4e).

\section{Archaeometra GISLÉN 1924.}

Archaeometra scrobiculata (MüNSTER in GOLDFUSS, 1831), Fig. 13.

1831 Solanocrinites scrobiculatus MÜNSTER in GOLDFUSs1826-1833, p. 167; pl. 50, fig. 8.

1876 Solanocrinus scrobiculatus GoldFuss, Quenstedt, p. 177 ; pl. 96, fig. 52-76.

1879 Antedon scrobiculatus (MÜNSTER), Loriol, p. 255; pl. 20, fig. 11-12.

1881 Antedon scrobiculata (GoldFuss), Carpenter, p. 203; pl. 10, fig. 14-18.

1887 Antedon scrobiculatus MüNSTER, Loriol, p. 452; pl. 214, fig. 2-4; pl. 215, fig. 1. 
1924 Archaeometra scrobiculata (GoldFuss), Gislén, p. 158.

1975 Archaeometra scrobiculata (MüNSTER), Hess, p. 61; pl. 21, fig. 5-6.

Material. Four cups with centrodorsal (Fig. 13e, f, i, j), three cups (radial circlets with attached basals, Fig. 13a), one centrodorsal with four attached basals (Fig. 13b), six centrodorsals (Fig. 13c, d, g, h).

Locality and horizon. Andelot-Morval, (Département Jura, France); Early Oxfordian.

Diagnosis. Large species. Centrodorsal hemispherical in juvenile and cone-shaped in adult specimens, interradial ridges produced, prolonged on the adoral side as curved ledges for the basals surrounding narrow central cavity; cirrus sockets smooth, directed downwards with overhanging, slanting roof; in adult specimens each radial section with sockets in 3-4 irregular rows of one or two; sockets diminish in size aborally, but small sockets may occur adorally. Basal circlet deeply sunken into the radial circlet; basals strong prismatic rods resting on the ledges of the centrodorsal, tips well exposed interradially. Radial circlet of variable height, with large exposed aboral surface; radial articular facets separated interradially by furrow; height of facets at least half the total height of radial; aboral ligament fossa wide and with deep pit; interarticular ligament fossae triangular and commonly separated from the muscle fossae by a ridge, adoral muscle fossae scalloped, may be nearly vertical distally, separated by a deep notch extending to the rim around the axial canal.

Description. The available specimens vary greatly in size. Small, juvenile centrodorsals are hemispherical and have only a few cirrus sockets; their adoral surface is dominated by interradial ledges that curve upwards and form a ring around the narrow centrodorsal cavity. Larger centrodorsals are cone-shaped and proximally wider than high (Fig. 13b); intermediate-sized centrodorsals may be higher than wide (Fig. 13h), but the largest centrodorsals are approximately as high as wide proximally. In most larger, subadult to adult specimens (Fig. 13e, f, i, j) the ridges are prolonged downwards where they separate the radial areas. The cirrus sockets are circular to oval and smooth. Most of the sockets are directed downwards with an overhanging roof; the few directed outwards are surrounded by a rim (Fig. 13h2). The basal circlet is deeply sunken into the radial circlet on the proximal side of the cup; in the central opening is a rosettelike structure with radial spokes (Fig. 13a1). The specimen in Fig. 13b has one of the basals missing while the others are seen from the side as high, prismatic rods sitting on the ledges of the centrodorsal; the basals are united centrally only in a
Fig. 10 Comatulid and isocrinid ossicles from the early Late Oxfordian, Savigna $2 \mathrm{~b}(\mathbf{a}-\mathbf{l})$. a-c Radials assigned to Paleocomaster musculosus n. sp. a Proximal (lower) facet of small rectangular radial, note nerve canals to basals below and large canals to adjoining radials above, M11364. b Distal view of rectangular radial with facet to first primibrachial, M11365. c Lateral-distal view of radial, M11366. d Narrow radial of a comatulid species, possibly Andymetra galei n. sp., note high muscle fossae, M11367, d1 proximal (lower) view with facets to basals and adjoining radials, note nerve canals to basals and adjoining radials, $\mathbf{d} \mathbf{2}$ distal view with facet to first primibrachial. e-h Syzygial facets of comatulid species. e Proximal facet of epizygal secundibrachial with coarse ridges, other side muscular without pinnule socket; M11312. f Proximal facet of epizygal secundibrachial with coarse ridges, other side muscular without pinnule socket; M11311. g Proximal facet of epizygal secundibrachial with coarse syzygy of fewer ridges, other side muscular with pinnule socket; M11313. h Coarse syzygy of few ridges on proximal facet of epizygal secundibrachial with ornamented latus, other facet is muscular with pinnule socket; M11310. i Proximal, synarthrial facet of low second primibrachial, possibly belonging to Isocrinus munieri; M11309. j-k Ossicles with synarthrial facets of a comatulid species (possibly same species as d). j Proximal, synarthrial facet of narrow secundibrachial, other side muscular with pinnule socket (at upper right); M11308. k Proximal synarthrial facet of second primibrachial, M11368. I Distal facet of large secundibrachial with pinnule socket and ornamented latus, other facet muscular; possibly belonging to Isocrinus munieri (LoRIOL); M11307. Columnals and cirrals of Isocrinus munieri (LoRIOL), early Late Oxfordian, Savigna 1 (m-u). m Proximal (upper) facet of proximal nodal, M11314. n Symplectial facet of thin proximal internodal, M11316. o Thin, cryptosymplectial facet of proximal internodal with fossulae, M11315. p Proximal facet of nodal, M11317. q Lateral view of nodal, M11318. $\mathbf{r}$ Lateral view of pluricolumnal of 8 internodals, M11319. s Facet of proximal cirral, M11322. t Lateral view of median cirral, M11321. u Lateral view of distal cirral, M11320

narrow part. The upper side of the basals connects to the radials by a slightly rugose surface, while the exposed outer surface is smooth. ŽítT (1980, fig. 1-2) figured a specimen of Archaeometra koprivnicensis (REMEŠ) from the Lower Cretaceous of Štramberk showing a similar basal in contact with two radials. It has stereom deposits at the base of the radial cavity, comparable to the specimen in Fig. 13b. The exposed surface of the radials varies considerably in size, but is invariably smooth. The radial articular facets are more or less inclined, but may rise almost vertically in the distal part (Fig. 13j). The size of the scalloped muscle fossae varies in the different specimens; they may be higher than the rest of the articular facet and are separated by a deep median notch extending to the rim of the axial canal (Fig. 13a2). The interarticular ligament areas are triangular and separated from the muscle fossae by a ridge (Fig. 13f). The radial cavity is moderately wide and star-shaped, with five blunt, petaloid rays. These correspond to the interradial angles of the cup as described by Carpenter (1881, p. 204). The distal edges of the muscle fossae are somewhat thickened and everted to produce the more or less petaloid figure surrounding the radial cavity. 


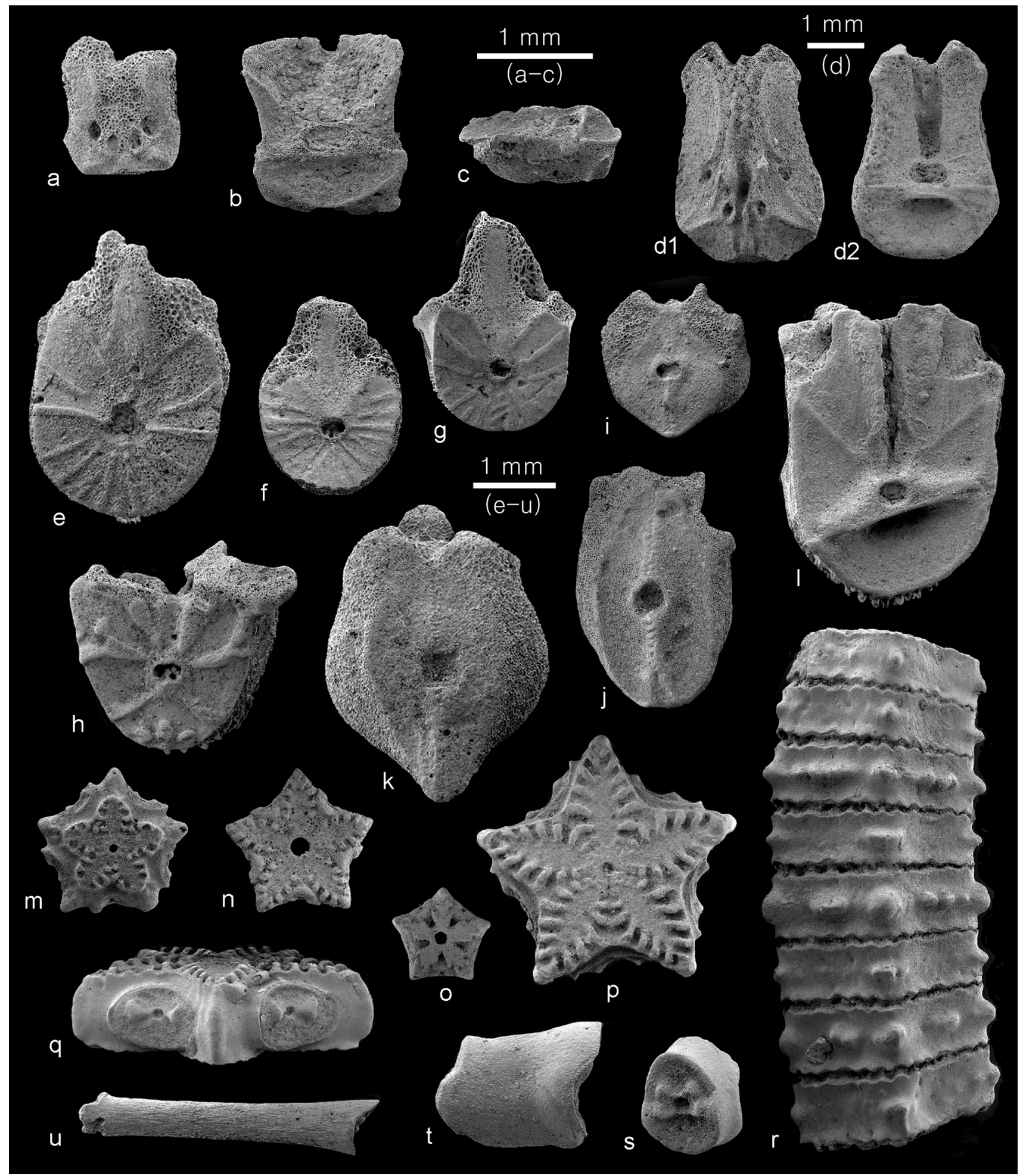

Remarks. Archaeometra was established by Gislén (1924) with Solanocrinus asper QUENSTEDT (1858) as the type species. This is somewhat unfortunate because A. scrobiculata is the much better known species. Gislén (1924, p. 158) suggested a revision of the species because the "centrodorsal varies from a rather low cone to a high and narrow column". Such differences between specimens from different horizons and localities were discussed by Carpenter (1881) who did not see a necessity for separate species. The present material documents the existence of 


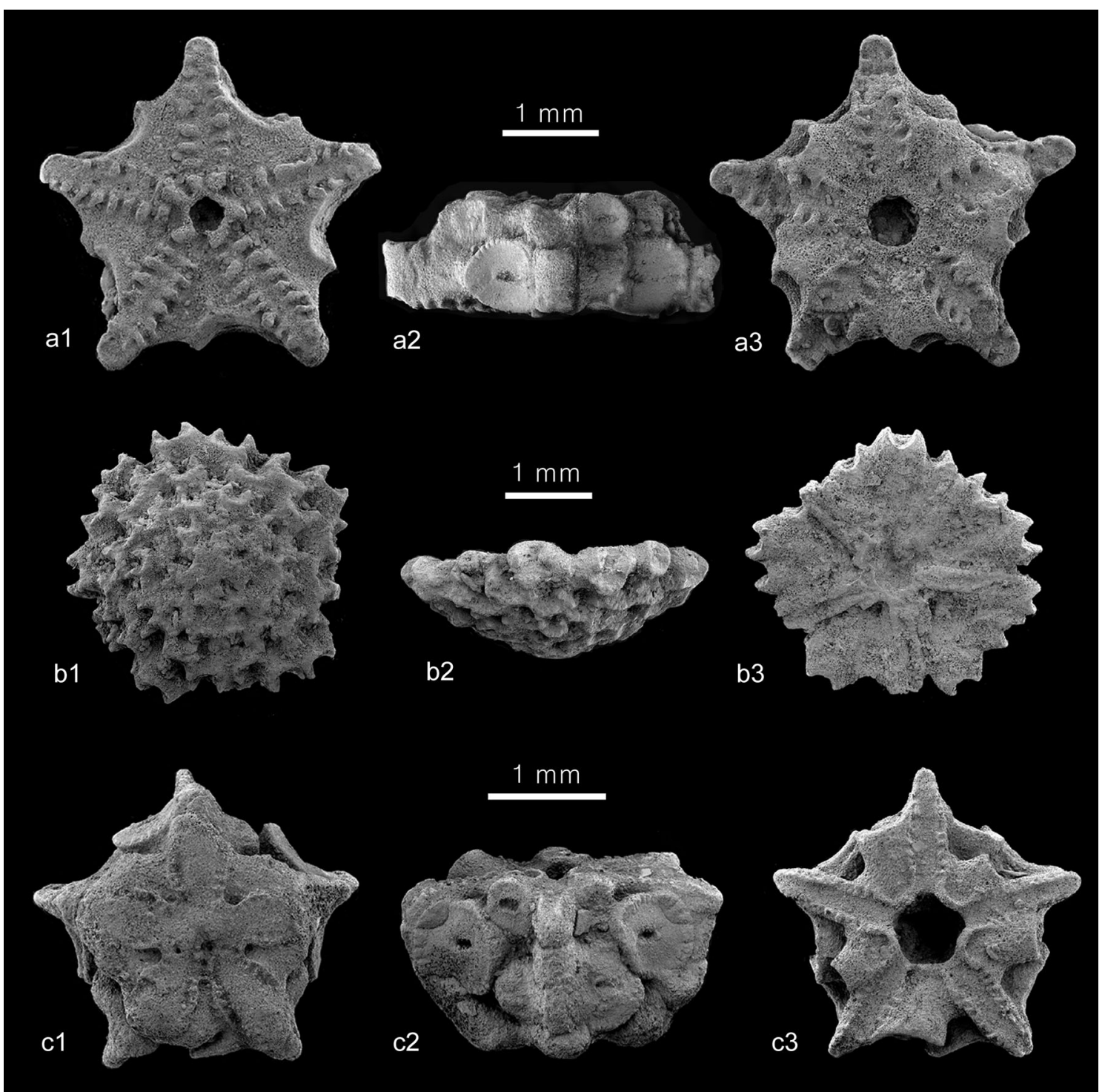

Fig. 11 Paracomatulid and comatulids, Early Oxfordian, AndelotMorval. a Centrodorsal of Paracomatula morator n. sp., holotype, M11229, a1 aboral, a2 lateral, a3 adoral. b Centrodorsal of

considerable variation between specimens from a single locality. The occurrence of a small basal rosette at the base of the radial cavity in the presence of stout basal rods is surprising. Basal rosettes commonly occur in extant antedonids where they replace the basals (Hess and Messing 2011). However, the occurrence of basal rods in the presence of a rosette has also been figured in a living comatulid (Hess and Messing 2011, p. 6, fig. 3). A. scrobiculata (Münster in Goldfuss, 1831) and A. aspera (QuenstedT 1858) are known from cups with centrodorsal and brachials; the described material (Quenstedt 1876; Loriol 1879, 1888 ) is from the sponge facies (Facies à Scyphies). So far,
Semiometra petitclerci (CAILLET), M11230, b1 aboral, b2 lateral, b3 adoral. c Centrodorsal of Palaeocomaster musculosus n. sp., M11231, c1 aboral, c2 lateral, c3 adoral

A. scrobiculata does not seem to have been recorded in Early to Middle Oxfordian mudstones, making the Andelot occurrence a new one and the oldest. In view of the discussions by Carpenter (1881) and Gislén (1924) on the variability of this species the well preserved Andelot material is a significant contribution.

Andymetra Hess 2012.

Andymetra donovani n. sp., Fig. 12c.

Material. One centrodorsal.

Holotype. Centrodorsal, M11228, Fig. 12c. 


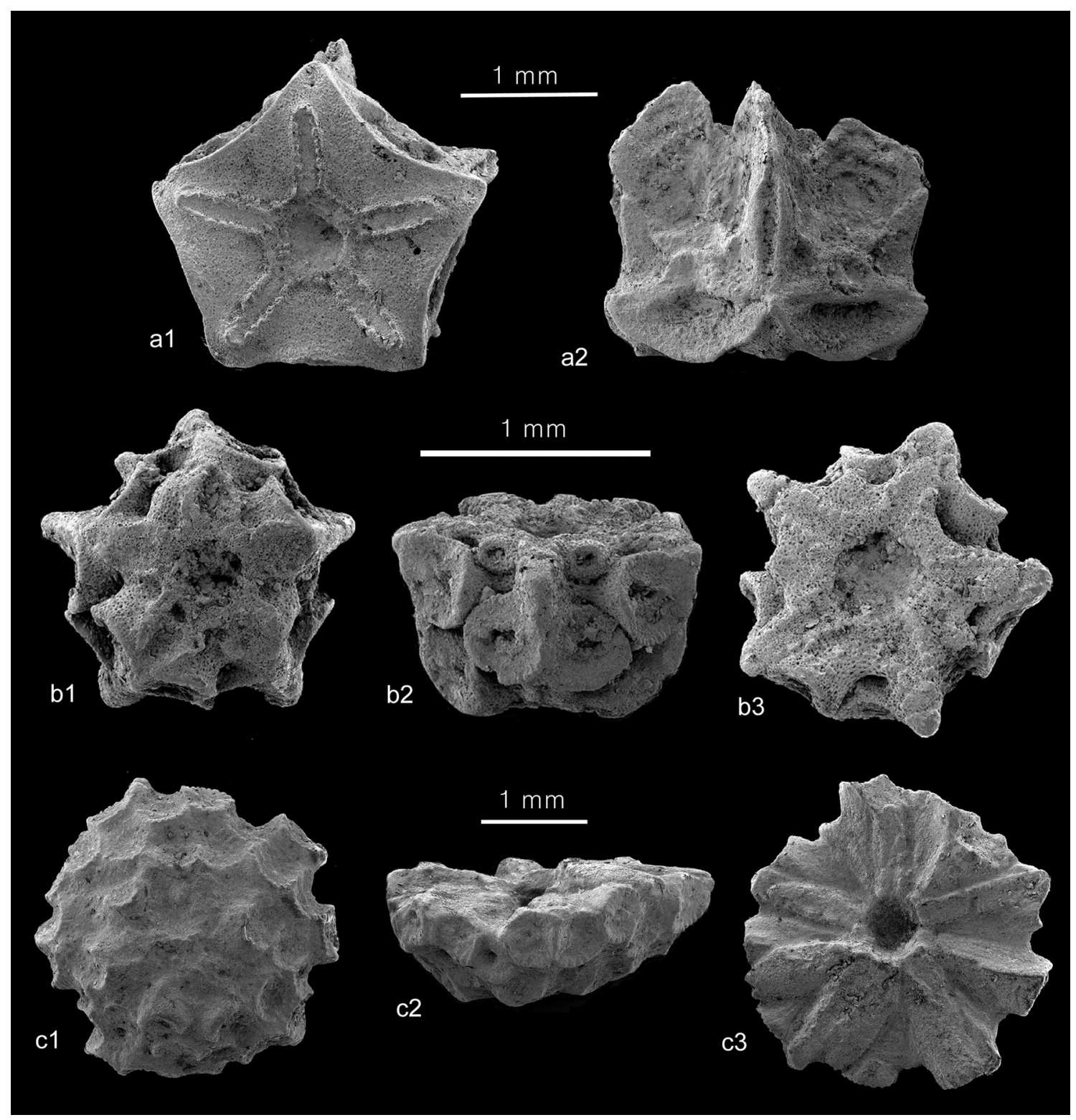

Fig. 12 Comatulids, early Late Oxfordian, Savigna 2b. Palaeocomaster musculosus n. sp. a Cup with embedded basal circlet, holotype, M11226, a1 proximal, a2 lateral, b centrodorsal, paratype,

Etymology. Dedicated to Steve Donovan for his unending enthusiasm in crinoids, "the most beautiful of fossils".

Type locality and horizon. Savigna, $10 \mathrm{~km}$ SSW of Orgelet, Département du Jura, France (see Gale 2011); Couches d'Effingen (Enay 1966), Stenocycloides Subzone of the Bifurcatus Zone, early Late Oxfordian.

Diagnosis. Centrodorsal circular, low bowl-shaped with irregular adoral side where weak impressions of narrow basals are seen in two or three places; cirrus sockets in two or three irregular rows, not forming columns and hardly
M11227, b1 aboral, b2 lateral, b3 adoral. c Centrodorsal of Andymetra donovani $\mathrm{n}$. sp., holotype, M11228, c1 aboral, c2 lateral, c3 adoral

sculptured; apex without small cirrus-free area; centrodorsal cavity $16 \%$ of centrodorsal diameter.

Description. The centrodorsal is a low bowl with rather large, smooth cirrus sockets irregularly distributed in two or three rows. The sockets extend to the slightly rugose aboral apex. The adoral side shows a narrow centrodorsal cavity and finger-like, flat or angular projections towards the margin. Two of the projections are narrow and have a crenulated margin, indicating that they supported narrow basals. Projections with sharp ridges are interradial in position. 


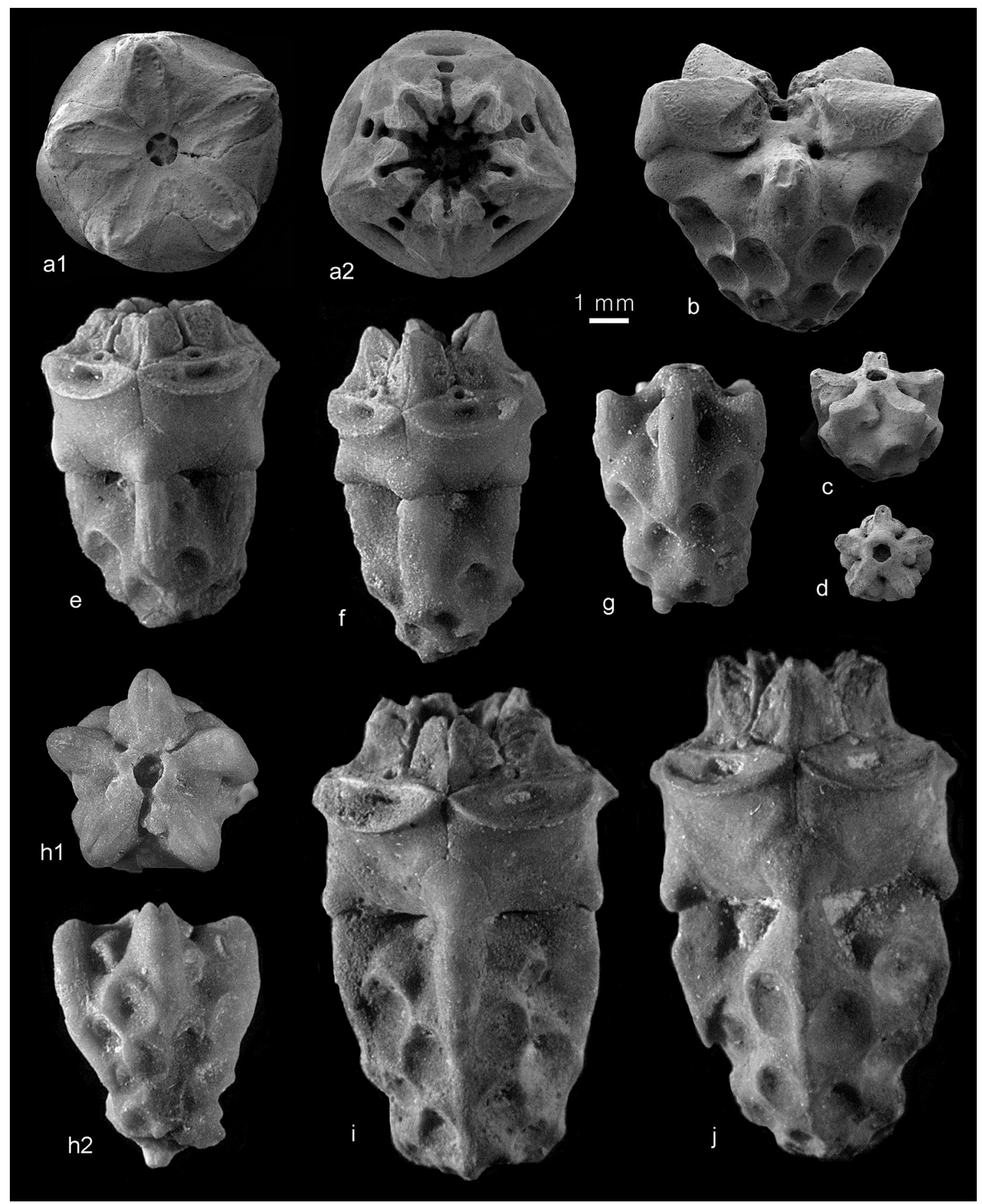

Fig. 13 Archaeometra scrobiculata (GoldFuss), Early Oxfordian, Andelot-Morval; the figured specimens show the size and variability of the species from this outcrop. a Radial circlet with embedded basals, M11241, a1 proximal, note basal rosette in center, $\mathbf{a} 2$ distal. b Oblique lateral-upper (distal) view of centrodorsal with four basals, basal in foreground missing, M11242. $\mathbf{c}$ Oblique upper-lateral view of small hemispherical centrodorsal, note elevated ledges for the basals, M11243. d Upper view of smallest centrodorsal from the outcrop, M11359. Lateral view of smaller cups with centrodorsal, e cup with high free radial surface and low articular facets, M11244, $\mathbf{f}$ cup with lower free radial surface and high articular facets, M11245. g Centrodorsal, M11246. h Centrodorsal with circular, rimmed cirrus sockets, M11360, h1 adoral, with flat, slightly crenulated ledges for the basals, h2 lateral view. i Lateral view of large cup with centrodorsal, radials with moderately high muscle fossae, M11361. j Large cup with comparatively low centrodorsal, muscle fossae high, M11362 
Remarks. The centrodorsal of this species differs from that of the Bathonian A. galei Hess (2012) by the lower height with consequently less cirrus sockets (33 in the present species, 41 in $A$. galei) and by the strongly sculptured adoral surface with raised bases of cirrus sockets. The equally flat centrodorsal of Semiometra petitclerci has smaller sockets seen as jagged margin of the flat adoral surface. The apex of $A$. donovani n. sp. lacks a dorsal star, although this is weak in the specimen of $S$. petitclerci described in the following.

Superfamily Notocrinoidea Mortensen, 1918.

Family Notocrinidae Mortensen, 1918.

Semiometra GisLÉN1924.

Semiometra petitclerci (CAILlET1923), Fig. 11b.

1923 Antedon petitclerci CAILleT, p. 125; pl. 1, fig. 1-3. 2007 Semiometra petitclerci (CAILlET), Radwańska, p. 165; text-fig. 3, pl. 1-2.

Material. One centrodorsal, M11230, Fig. 11b, from Andelot-Morval (Dépt. Jura, France); Early Oxfordian.

Description. The centrodorsal is low bowl-shaped with roughly pentagonal outline and a jagged margin caused by the deep cirrus sockets extending to the adoral side. The aboral pole is convex, and only the center is free from cirrus sockets. The approximately 40 sockets are in three irregular rows, and their diameter diminishes from the upper edge of the centrodorsal to the aboral pole. The pole is surrounded by some irregular oval pits that may represent a weak dorsal star. The adoral surface is nearly flat with five more or less distinct rod-shaped impressions for the basals. The shallow centrodorsal cavity has a diameter of $12 \%$ of centrodorsal diameter.

Remarks. The present centrodorsal is referred to Semiometra petitclerci described from the Lower Oxfordian (marnes oxfordiennes) of Authoison (Dépt. Haute-Saône). Caillet's specimens, a centrodorsal and two cups with centrodorsal, have a diameter of $3 \mathrm{~mm}$, as the present specimen. Their centrodorsal is similar in shape and development of cirrus sockets, but they have a very distinct dorsal star on the otherwise naked aboral pole. In the Andelot specimen the cirrus sockets almost reach the aboral pole and the dorsal star (five oval slits around the apex) is indistinct. However, this may be due to some recrystallization. The species has also been recorded from the Upper Oxfordian of Poland (Radwańska 2007). The Polish specimens are three well-preserved cups with attached centrodorsal. The centrodorsal is almost discoidal and, thus, has only about 27 cirrus sockets, compared with about 40 in the Andelot specimen. Helm et al. (2003) described a well-preserved cup with centrodorsal from the Middle Oxfordian of northwestern Germany as a different species, Semiometra ithiensis. It is very similar to $S$. petitclerci, including the distinct dorsal star. As suggested by Radwańska (2007) the two forms may be conspecific.

Undeterminate radials, primibrachials and secundibrachials

Among the cup plates and brachials from Savigna that cannot be assigned to $B$. brachiospina n. sp. are three radials: two first primibrachials with distal synarthry; one second, axillary primibrachial with proximal synarthry; one secundibrachial with synarthry; 148 secundibrachials with one or the other kind of syzygy, the hypozygals and epizygals occur in similar number; 77 secundibrachials with muscular articulations, one of them with a proximal synostosis. All these brachials lack thorns, and some have a finely ornamented latus (Fig. 101). Many of the ossicles are narrow, with a wide aboral-adoral diameter resulting in facets with oval profile (Fig. 10k, j). Rectangular (Fig. 10a-c) or narrow (Fig. 10d) radials differ much from the radials of $B$. brachiospina $\mathrm{n}$. sp. and also from radials of other isocrinids. The radials in Fig. 10a-c seem to belong to Palaeocomaster musculosus n. sp. The narrow radial with high muscle fossae (Fig. 10d) may have belonged to Andymetra donovani n. sp. It resembles many extant comatulids, e. g. the antedonid Florometra as figured by Clark (1921, pl. 5, fig. 1008-1009, 1011) and Janevski and Baumiller (2010, fig. 10A). Narrow articulations with high muscle fossae have been discussed as a prerequisite for swimming in comatulids (Janevski and Baumiller 2010), and the presence of such a radial in the presence of an antedonid-like centrodorsal like $A$. donovani n. sp. suggests that perhaps this early comatulid had the potential to swim. Primibrachials vary in shape, but they are connected by synarthrial facets (Fig. 10i, k). The narrow primibrachial (Fig. 10k) is ascribed to a comatulid, presumably the same species as in Fig. 10d; and the narrow synarthrial secundibrachial (Fig. 10j) may be from the same species. The wide second primibrachial (Fig. 10i) may have belonged to Isocrinus munieri. Syzygial facets of secundibrachials vary in number and strength of ridges (Fig. 10e-h), but in view of their similar shape the brachials seem to belong to a single species. Such syzygies are unknown in Isocrinus. Similar syzygies from the Bathonian of the Ardèche were tentatively assigned to species of Balanocrinus (Hess 2012), while comatulids were ruled out because of their rarity. The present material presents the same problem. However, B. brachiospina n. sp. is the only species of the genus at Savigna, and it definitely lacks syzygies. Thus, such brachials must have belonged to one of the comatulid 


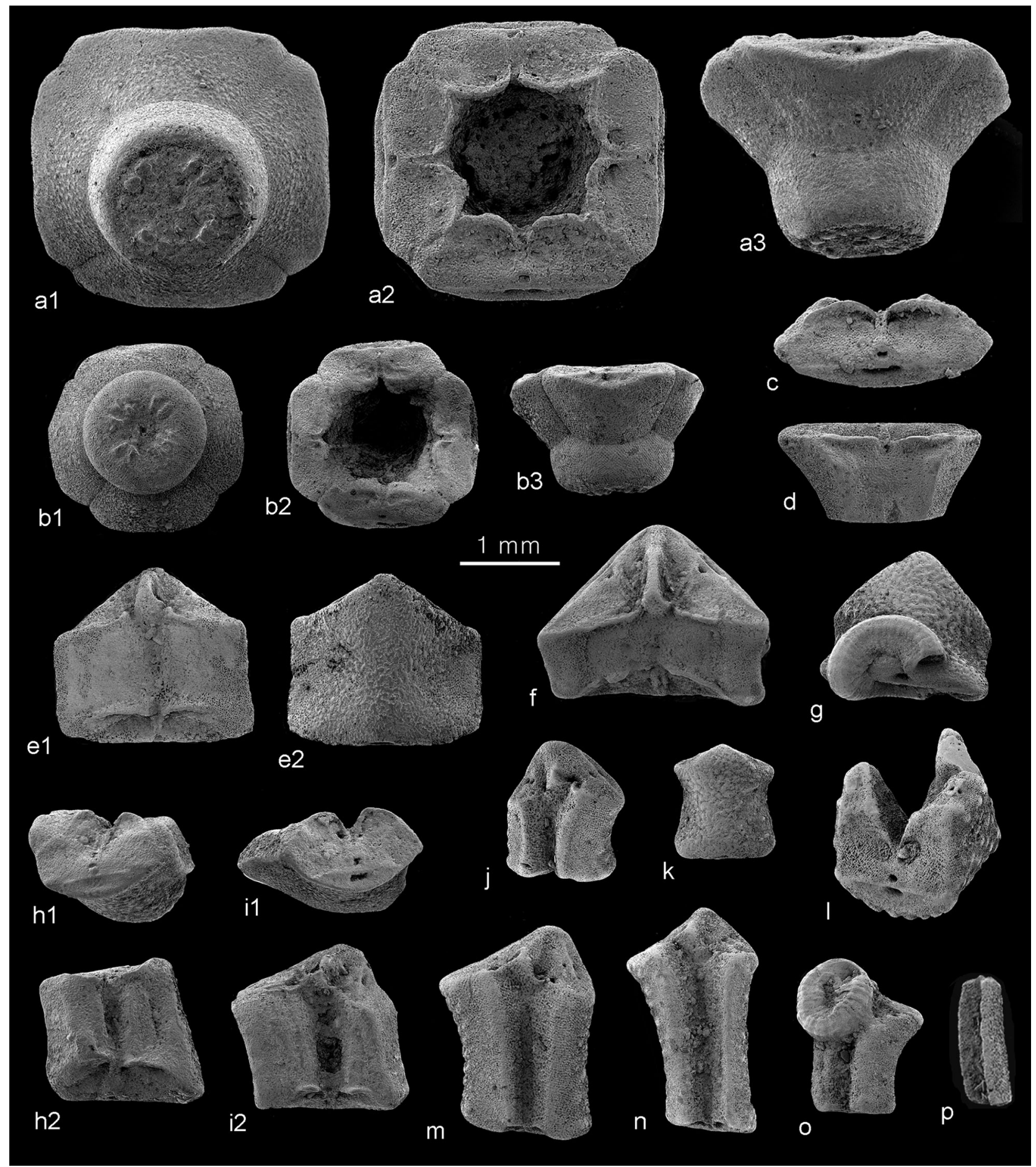

Fig. 14 Tetracrinus galei n. sp., Early Oxfordian, Andelot-Morval. a Cup (radial circlet with basal element), holotype, M11383, a1 proximal, a2 distal, a3 lateral. b Cup, M11384, b1 proximal, b2 distal, b3 lateral. c Distal view of radial (radial articular facet), M11385. d Adoral view of radial, M11397. e Axillary, fused first and second primibrachials, paratype, M11388, e1 adoral, e2 aboral. f Adoral view of axillary with large, asymmetric facets to first secundibrachials, M11398. g Aboral view of axillary with granular surface and epizoic serpulid, M11387. h First secundibrachial, M11391, h1 distal facet (note absence of pinnule socket), h2 adoral (note asymmetric facet to axillary primibrachial). i Proximal secundibrachial, M11392, i1 distal facet with pinnule socket, i2 adoral (note pinnule socket at right). $\mathbf{j}$ Adoral view of small, median secundibrachial, M11390. $\mathbf{k}$ Aboral view of small, high axillary of fused first and second primibrachials, M11386. I Proximal view of low secundibrachial with lateral extension on distal side of pinnule socket, M11395. m Adoral view of secundibrachial with large pinnule socket at right, M11393. n Adoral view of distal secundibrachial with pinnule socket, M11394. o Adoral view of secundibrachial with enlarged, possibly pathological pinnule socket, M11389. p Oblique adoral view of pinnular tentatively assigned to T. galei n. sp., M11396 


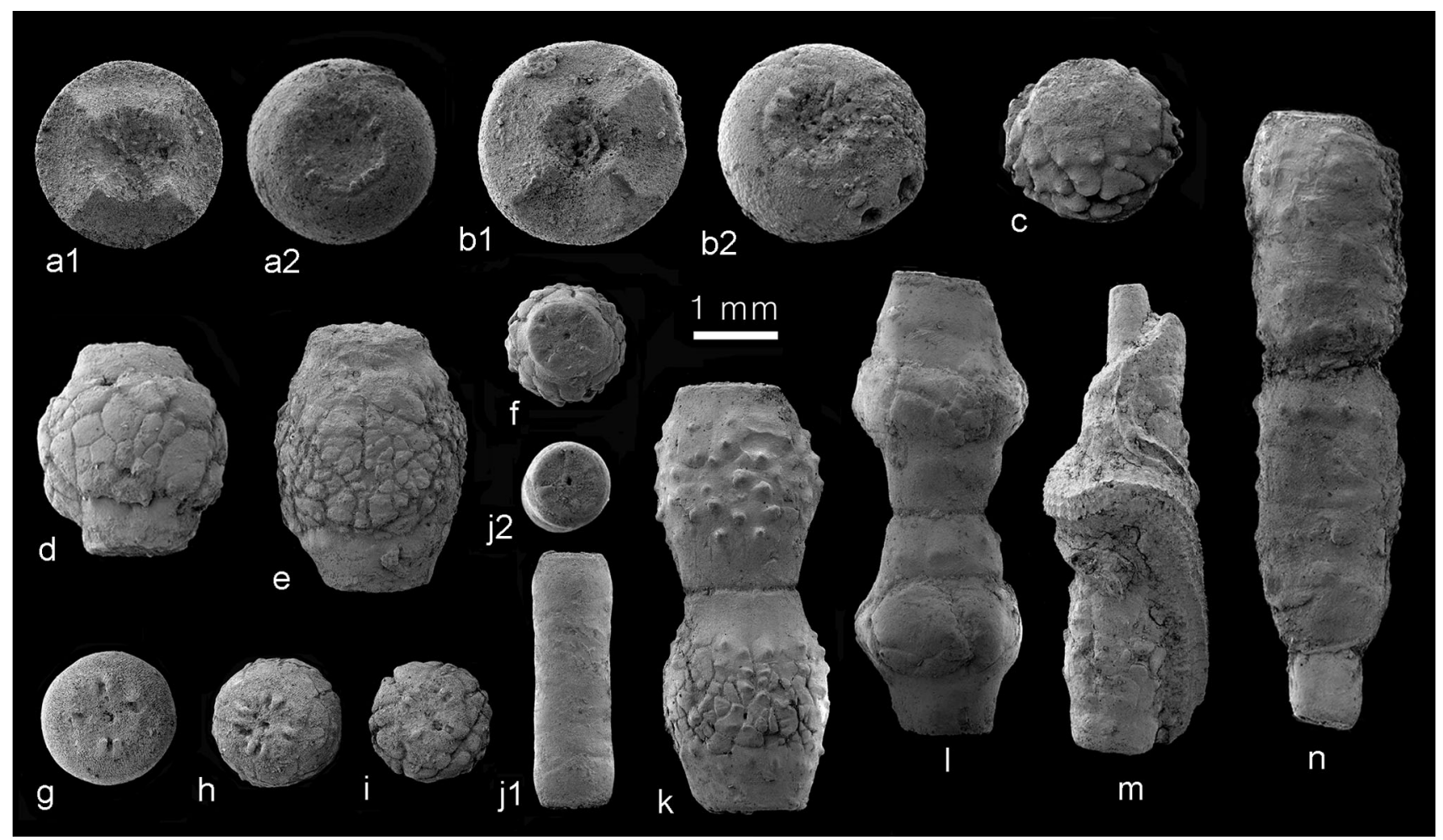

Fig. 15 Tetracrinus galei n. sp., Early Oxfordian, Andelot-Morval. Basal elements (fused basal circlets). a Element with wide depression below radial cavity, M11399, a1 distal (upper) facet, a2 proximal (lower) facet (to column). b Element with narrow depression below radial cavity, M11400, b1 distal (upper) facet, b2 proximal (lower) facet, note two pits of Ooichnus paraboloides BRomLey at lower right. c Oblique lateral view of strongly granular spherical columnal, M11401. d Lateral view of columnal with collar of irregular, tesselated elements, M11402. e Lateral view of higher columnal with tesselated sculpturing, paratype, M11403. f Facet of low columnal with tesselated sculpturing, M11404. g Tetramerous facet of smooth, low columnal, M11405. h Tetramerous facet of slightly granular,

species despite the wide discrepancy in the number of centrodorsals/cups and brachials. This may be due to selective transport of the small ossicles to the site of deposition. Jäger (2010) noted a similar, though less pronounced, discrepancy between the number of cups or centrodorsals of two comatulid species and the assignable brachials (that include syzygies) in a Barremian fauna of southeastern France. Secundibrachials with muscular articulation (Fig. 101) may well have belonged to Isocrinus munieri.

Order Cyrtocrinida SieverTs-DoReCK, 1952.

Suborder Cyrtocrinina SieVERTS-DoReCK, 1952.

Superfamily Plicatocrinoidea ZitTel, 1879.

Family Tetracrinidae Nicosia 1991.

Tetracrinus MÜNSTER, 1839.

Tetracrinus galei n. sp., Figs. 14, 15.

Material. Three cups with basal element, one cup of two radials with basal element, 19 basal elements, 23 radials, nearly spherical columnal, M11406. i Facet of higher columnal with median band of irregular, tesselated to rugose sculpturing, M11407. j High, smooth to weakly granular columnal, M11408, j1 lateral, j2 upper, tetramerous facet. $\mathbf{k}$ Pluricolumnal of two barrel-shaped columnals with ribbons of granules, M11409. I Pluricolumnal of two with swollen and tesselated median part, M11410. m Pluricolumnal of two with serpulid overgrowth, the tessellated sheet of the upper columnal is partly broken away exposing a thin, smooth column core; M11415. n Pluricolumnal of two cylindrical columnals with small, protruding smooth part, presumably the core for accretion of a mantle as in specimen m; M11411

46 fused axillary primibrachials, 17 first secundibrachials without pinnule socket, 121 secundibrachials with pinnule socket, 273 single columnals, 26 pluricolumnals of 2 and 3 pluricolumnals of 3 . The number of basal elements indicates the presence of 19 individuals; but the number of cups, radials and primibrachials is too low for a proper match. The 334 columnals suggest that each basal circlet was attached to a column of about 17 elements, a number seemingly too high for a cyrtocrinid. Thus, some sorting of the different ossicle types must be assumed.

Holotype. Cup with basal element, Fig. 14a, M11383.

Paratypes. Axillary primibrachial, Fig. 14e, M11388; columnal, Fig. 15e, M11403.

Etymology. Dedicated to Andy Gale, for providing the material and his work on Jurassic asteroids.

Type locality and horizon. Andelot-Morval (Département Jura, France), late Early Oxfordian. 
Diagnosis. Cup conical, composed of fused basal circlet and circlet of four radials, the circlets not separated by a distinct constriction or deep furrow. Primibrachials fused to axillary, following secundibrachials elongated, no further arm division; first pinnule on second secundibrachial. Surface of basal and radial circlets, primibrachials and proximal secundibrachials smooth or finely granular; distal, elongated secundibrachials with scattered larger granules. Columnals widely variable in shape, length and ornamentation, surface commonly tesselated, especially in barrelshaped elements where the ornamentation may be restricted to the middle part, surface of other columnals with irregular or scattered granules, or smooth. Attachment unknown.

Description. The two figured cups are of different size. In the holotype (Fig. 14a) the basal and radial circlets blend into one another, while in the smaller cup the suture between the elements is more visible (Fig. 14b). The surface of both cups is finely granular to smooth. The diameter of the radial cavity is half of total diameter. The radial articular facets have a narrow aboral ligament with an elongated pit, the interarticular ligaments are indistinct, and the muscle fossae are shallow and large, with distinct lips bordering the radial cavity and separated by a notch, also visible in adoral view (Fig. 14d). The basal elements vary in height and diameter of the shallow depression below the radial cavity (Fig. 15a-b). The lower (proximal) facet of the basal elements may vary in diameter to some extent; there are four groups of two crenulae each, which may vary in length (Fig. 15a2, b2). The two primibrachials are fused into one element of variable height and thickness. The aboral surface is finely granular (Fig. 14e-g, k); the adoral surface has a median part with furrow, the facets to the first secundibrachials vary in height and may occupy nearly half the height of the ossicle (Fig. 14f); the facet to the radial with corresponding lips is also visible to some extent (Fig. $14 \mathrm{e} 1, \mathrm{f}$ ). The facets to the first secundibrachials may be unequal (Fig. 14e1, f), matching their proximal facet (Fig. 14h2). The first secundibrachial lacks a pinnule socket. The first pinnule is on the second secundibrachial (Fig. 14i); the proximal facet of this ossicle has muscle fossae bordered by a lip. The following secundibrachials are increasingly high, and the diameter is reduced. Pinnule sockets are prominent (Fig. 14j, m, n), giving the brachials the superficial appearance of an axillary. However, no secondary axillary has been identified so that the arms branched only at the primibrachial. The aboral surface of the secundibrachials is mostly granular. The articular facets show a distinct aboral pit, a narrow transverse ridge, flat and indistinct interarticular ligament fossae and a pair of deep, small muscle fossae, separated by an adoral notch (Fig. 141). One secundibrachial has a curious, nearly circular and possibly pathological cirrus socket (Fig. 14o). A high pinnular (Fig. 14p) may have belonged to this species; no fused, daggerlike pinnule as occurring in Tetracrinus moniliformis (see Hess and Messing 2011, fig. 96,1 h) could be found. The columnals vary greatly in height, shape and ornamentation (Fig. 15c-n). They all have facets with more or less produced groups of 4 crenulae, and the lumen is invariably small. Shapes vary from nearly spherical to barrel-shaped or cylindrical. The latera are ornamented by sparse, small (Fig. 15j) or large granules (Fig. 15c, k), or they are irregularly tessellated (Fig. 15d-f, i, l-n); ornamentation commonly is concentrated in a median band (Fig. 15d-e, k-1). The two specimens in Fig. $15 \mathrm{~m}-\mathrm{n}$ show a smooth, thin columnal emanating from a thicker, ornamented columnal. This indicates that the diameter increased by accretionary growth on a smooth core. A basal element of Tetracrinus galei n. sp. has two pits of Ooichnus paraboloides BROMLEY (Fig. 15b2); this epizoan commensal commonly occurs in the Middle Jurassic cyrtocrinid Cyrtocrinus praenutans Hess (2012).

Remarks. The occurrence of a species of Tetracrinus in a mudstone sequence is somewhat surprising because most records of these cyrtocrinids are from hardgrounds or spongal reef environments. It should be noted, however, that the attachment of plicatocrinoids and, thus, tetracrinids is unknown. Jaekel (1892) recorded two species of Tetracrinus from the Oxfordian. The type species of the genus, T. moniliformis (MüNSTER in GoldFuss) is known from cups (radial circlet with attached basal element), isolated radials and basal elements, fused primibrachials, secundibrachials and columnals. Pinnulars and attachment structures were not described by Jaekel who refigured Quenstedt's (1876) material at a larger scale. Loriol (1882) described ossicles from the Oxfordian of Le Pontet near Saint-Claude that are comparable to those in Jaekel's paper; in particular he figured a radial circlet attached to its basal element (pl. 19, fig. 1) that is much lower than in the present species. Jaekel (1892, p. 648) proposed a second species from the Oxfordian of Poland, T. langenhani, based on limited material. This species is distinguished by thicker radials and more elongated secundibrachials but appears to be conspecific with moniliformis (see also Salamon 2008, p. 86). SievertsDoreck (1964) described additional material from the Late Jurassic sponge facies (Oxfordian), and she recorded unnamed elements (columnals, basals, radials, brachials, pinnulars) from the Lower Jurassic (Pliensbachian-Toarcian), Middle Jurassic (Bajocian, Callovian) and the Upper Jurassic (Kimmeridgian/Tithonian) of Swabia. Arendt (1974) figured cups and columnals from the Kimmeridgian of Brno (Czech Republic), including a pluricolumnal of 7; the radial and basal circlets are separated by a constriction 
as in Jaekel's figures, and the surface is mostly granular or abraded. Hess (1975) figured basal circlets, radials, fused primibrachials, brachials and fused pinnulars from the Middle Oxfordian Birmenstorf Member of Switzerland; all elements have a densely granular surface. Zatoń et al. (2008) figured a basal circlet, a columnal and three brachials of T. moniliformis from the Middle Oxfordian (Transversarium Zone) of the Polish Jura. Salamon (2008) described basal circlets and brachials of the same species from the Late Callovian of Poland. None of these papers adds much to the knowledge of $T$. moniliformis as described by Jaekel (1892). Salamon and Gorzelak (2010a) proposed T. baumilleri from the Tithonian on the basis of some basal circlets and numerous brachials; the species is distinguished from the type species by a high basal circlet. The stratigraphically youngest tetracrinid named so far is Tetracrinus jagti Salamon et al. (2007) from the Cenomanian of Poland; it is based on a smooth, flat basal circlet. Finally, Salamon and Gorzelak (2010b) figured an unnamed basal circlet from the Campanian of Poland. Tetracrinus galei $\mathrm{n}$. $\mathrm{sp}$. is distinguished from all these remains by a conical cup, with basal element and radial circlet barely separated by a distinct constriction. Tetracrinus kocyigiti (kocigyiti in the figure caption) described by Nicosia (1991) from the Late Sinemurian-Early Pliensbachian of Turkey has five radials on a sloping basal circlet with only partly fused elements, and the radial cavity is narrow. The form does not resemble the typical Tetracrinus at all.

\section{Conclusions}

The large majority of the many species of isocrinids from the Jurassic is based on columnals that are easily recognised and collected in the field. However, the diagnostic value of such material and species based upon is limited. In rare cases intact specimens furnished additional information. Mudstones are a largely untapped treasure trove for information on crinoid morphology and taxonomy, not the least because they are easily sampled, and the washed residues furnish exquisitely preserved remains of echinoderms, as beautifully demonstrated by Gale for the asteroids (2011). In the present paper such information is used for extended diagnoses of common and widespread species of Balanocrinus. The large samples also yielded rare remains of comatulids that demonstrate an unexpected diversity early in their history. These finds are discussed in a parallel paper (Hess 2013b); and they add to the ongoing discussion on the various scenarios for the evolution of columns and cirri in Articulata (Rouse et al. 2013). An unexpected discovery is the presence of a new cyrtocrinid at one of the locations. It may be expected that future research on fossiliferous mudstones will richly reward those who make the effort to sample, process and pick the residues.

Acknowledgments I am most grateful to Andy Gale for providing most of the material described in the present paper. I wish to thank Walter Etter (Basel) for the line drawing, Günter Schweigert (Stuttgart) for information on stratigraphy, Paul Taylor (London) for information on bryozoans, M. Pika-Biolzi for information on the type material of Balanocrinus argoviensis (MoEsch), Lionel Cavin and Pierre-Alain Proz (Geneva) for information on Balanocrinus gillieroni, and the reviewers Hans Hagdorn and Mike Simms for their constructive comments. My best thanks are to Evi Bieler, Zentrum für Mikroskopie of the University of Basel, for her excellent SEM work.

\section{References}

Agassiz, J. L. R. (1836). Prodrome d'une Monographie des Radiaires ou Echinodermes. Mémoires de la Société des Sciences Naturelles de Neuchãtel, 1(1835), 168-199.

Arendt, Y. A. (1974). Morskie lilii. Tsirtokrinidy. Akad. Nauk SSSR, Paleont. Inst., Trudy, 144, 251 pp. Izdatelstvo "Nauka" (Moskva) [Sea lilies, Cyrtocrinids].

Bourseau, J.-P., David, J., Roux, M., Bertrand, D., \& Clochard, V. (1998). Balanocrinus maritimus nov. sp., crinoïde pédonculé nouveau du Kimméridgien inférieur de la Rochelle (CharenteMaritime, France). Geobios, 31, 215-227.

Caillet, H. (1923). Note sur un Antedon nouveau de l'Oxfordien. Bulletin de la Société Belfortaine d'Émulation, 38 (for 1922), 125-127.

Carpenter, P. H. (1881). On the genus Solanocrinus, Goldfuss, and its relations to recent Comatulae. Linnean Society of London (Zoology) Journal, 15, 187-217.

Carpenter, P. H. (1884-1888). Report upon the Crinoidea collected during the voyage of H.M.S. challenger during the years 18731876. Report of the Scientific Results of the Voyage of H.M.S. Challenger during the years 1873-1876, Zoology, Part I, General morphology, with descriptions of the stalked crinoids, 11 (1884), 442 pp.; Part II, The Comatulae, 26 (1888), 400 pp.

Charlesworth, E. (1847). New species of Pentacrinus in the Lias of Yorkshire. London Geology Journal, 2, 98.

Clark, A. H. (1908). New genera of unstalked crinoids. In Proceedings of the Biological Society of Washington, vol 21, pp. 125-136.

Clark, A. H. (1921). A monograph of the existing crinoids. United States National Museum, Bulletin 82:1 (The comatulids, 2), $795 \mathrm{pp}$.

Desor, E. (1845). Résumé de ses études sur les crinoïdes fossiles de la Suisse. Bulletin de la Société des Sciences Naturelles de Neuchãtel, 1(1845), 211-222.

Enay, R. (1966). L'Oxfordien dans la moité sud du Jura Français. Nouvelles Archives du Muséum d'Histoire naturelle de Lyon, fasc. $8: 1,310 \mathrm{pp}$.

Gale, A. S. (2011). Asteroidea (Echinodermata) from the Oxfordian (Late Jurassic) of Savigna, Département du Jura, France. Swiss Journal of Palaeontology, 130, 69-89.

Gislén, T. (1924). Echinoderm studies. Zoologiska Bidrag från Uppsala, 9, $316 \mathrm{pp}$.

Goldfuss, G. A. (1826-1833). Petrefacta Germaniae. Abbildungen und Beschreibungen der Petrefacten Deutschlands und der Angränzenden Länder, unter Mitwirkung des Herrn Grafen Georg zu Münster, herausgegeben von August Goldfuss. Band 1 (1826-1833), Divisio prima. Zoophytorum reliquiae: 1-114; Divisio secunda. Radiariorum reliquiae, 115-221 [Echinodermata]. Düsseldorf: Arnz \& Co. 
Gray, J. E. (1842). Synopsis of the contents of the British Museum, 44th ed... London: British museum, 308 pp

Gygi, R. (2000). Integrated Stratigraphy of the Oxfordian and Kimmeridgian (Late Jurassic) in northern Switzerland and adjacent southern Germany. Memoirs of the Swiss Academy of Sciences, 104, $151 \mathrm{pp}$.

Helm, C., Reuter, M., \& Schülke, I. (2003). Comatulid crinoids from Late Jurassic reefal deposits of NW Germany (Lower Saxony Basin). Neues Jahrbuch für Geologie und Paläontologie Monatshefte, 9, 513-528.

Hess, H. (1951). Ein neuer Crinoide aus dem mittleren Dogger der Nordschweiz (Paracomatula helvetica n. gen. n. sp.). Eclogae Geologicae Helvetiae, 43, 208-216.

Hess, H. (1960). Ophiurenreste aus dem Malm des Schweizer Juras und des Departements Haut-Rhin. Eclogae Geologicae Helvetiae, 53, 385-421.

Hess, H. (1966). Mikropaläontologische Untersuchungen an Ophiuren. V. Die Ophiuren aus dem Argovien (unteres Ober-Oxford) vom Guldenthal (Kt. Solothurn) und von Savigna (Dépt. Jura). Eclogae Geologicae Helvetiae, 59, 1025-1063.

Hess, H. (1972). Chariocrinus n. gen. für Isocrinus andreae Desor aus dem unteren Hauptrogenstein (Bajocien) des Basler Juras. Eclogae Geologicae Helvetiae, 65, 197-210.

Hess, H. (1975). Die fossilen Echinodermen des Schweizer Juras. Veröffentlichungen aus dem Naturhistorischen Museum Basel, 8, $130 \mathrm{pp}$.

Hess, H. (2006). Crinoids from the Lower Jurassic (Pliensbachian) of Arzo, southern Switzerland. Schweizerische Paläontologische Abhandlungen, $126,143 \mathrm{pp}$.

Hess, H. (2012). Crinoids from the Middle Jurassic (Bajocian-Lower Callovian) of Ardèche, France. Swiss Journal of Palaeontology, 131, 211-253.

Hess, H. (2013a). Balanocrinus (Crinoidea) from the the Jurassic: species concept, reconstruction, ontogeny, taphonomy and ecology. Swiss Journal of Palaeontology (in press).

Hess, H. (2013b). Origin and radiation of the comatulids (Crinoidea) in the Jurassic. Swiss Journal of Palaeontology (in press).

Hess, H., \& Messing, C. G. (2011). In W. I. Ausich (Ed.), Treatise on invertebrate paleontology, part T, Echinodermata 2, revised, Crinoidea Volume 3. Lawrence: The University of Kansas Paleontological Institute, $261 \mathrm{pp}$.

Hess, H., \& Spichiger, P. U. (2001). Argoviacrinus rarissimus n. g. n. sp., a new crinoid (Echinodermata) from the Middle Oxfordian of northern Switzerland. Eclogae Geologicae Helvetiae, 94, 489-494.

Jaekel, O. (1918). Phylogenie und System der Pelmatozoen. Paläontologische Zeitschrift, 3, 1-128.

Jaekel, O. (1892). Ueber Plicatocriniden, Hyocrinus und Saccocoma. Zeitschrift der Deutschen geologischen Gesellschaft, 44, 619-696

Jäger, M. (2010). Crinoids from the Barremian (Lower Cretaceous) of the Serre de Bleyton (Drôme, France). Annalen des Naturhistorischen Museums in Wien, Serie A, 112, 733-774.

Janevski, G. A., \& Baumiller, T. K. (2010). Could a stalked crinoid swim? A biomechanical model and characteristics of swimming crinoids. Palaios, 25, 588-596.

Klikushin, V. G. (1979a). The microstructure of the isocrinid columnals. Paleontological Journal (Paleontologicheskiy Zhurnal), 1, 88-96. (in Russian).

Klikushin, V. G. (1979b). Sea-lilies of Balanocrinus and Laevigatocrinus genus. Paleontological Journal (Paleontologicheskiy Zhurnal), 3, 87-96 (in Russian).

Klikushin, V. G. (1982). Taxonomic survey of fossil isocrinids with a list of the species found in the USSR. Geobios, 15, 299-325.

Klikushin, V. G. (1992). Fossil pentacrinid crinoids and their occurrence in the USSR. Leningrad Paleontological Laboratory, 358 pp (in Russian).
Klikushin, V. G. (1996). Late Jurassic crinoids from Sudak environs. Palaeontographica A, 238, 97-151.

Loriol, P. de (1877-1879). Monographie des crinoïdes fossiles de la Suisse. Mémoires de la Société Paléontologique Suisse, 4, 1-52 $(5,3-124 ; 6,125-300)$.

Loriol, P. de (1882-1889). Paléontologie française, Série 1, Animaux invertébrés. Terrain jurassique, 11, Crinoïdes, 1 (1882-1884) 627 pp. (2 (1884-1889) 580 pp. G. Masson: Paris).

Moesch, C. (1867). Geologische Beschreibung des Aargauer-Jura und der nördlichen Gebiete des Kantons Zürich. Beiträge zur geologischen Karte der Schweiz, 4, 319 pp.

Mortensen, T. (1918). The Crinoidea of the Swedish Antarctic Expedition. Wissenschaftliche Ergebnisse der Schwedischen Südpolar-Expedition 1901-1903, 4(8), 1-23.

Nicosia, U. (1991). Mesozoic crinoids from the north-western Turkey. Geologica Romana, 27, 389-436.

Quenstedt, F. A. (1856-1858). Der Jura, p. 1-842 (Lief. 1, p. 1-208, April 1856; Lief. 2, p. 209-368, Sept., 1856; Lief. 3, p. 369-576, Dec., 1856; Lief. 4, p. 577-842, May, 1857). Tübingen: Laupp.

Quenstedt, F. A. (1876). Petrefactenkunde Deutschlands. 1. Abt., 4. Band, Echinodermen (Asteriden und Encriniden), viii +742 pp. Leipzig: Fues's Verlag.

Radwańska, U. (2007). A rare comatulid crinoid, Semiometra petitclerci (Caillet, 1923), from the Upper Oxfordian of Poland. Acta Geologica Polonica, 57, 161-167.

Rasmussen, H. W. (1961). A monograph on the Cretaceous Crinoidea. Kongelige Danske Videnskaberne Selskab Biologiske Skrifter 12(1), $428 \mathrm{pp}$.

Roux, M. (1981). Echinodermes: Crinoïes Isocrinidae. In Résultats des campagnes Musorstom I, Philippines (18-28 mars 1976). Mémoires ORSTOM, 91, 477-543.

Rouse, G. W., Jermin, L. S., Wilson, N. G., Eeckhaut, I., Lanterbecq, D., Oji, T., et al. (2013). Fixed, free, and fixed: The fickle phylogeny of extant Crinoidea (Echinodermata) and their Permian-Triassic origin. Molecular Phylogenetics and Evolution, 66, 161-181.

Salamon, M. A. (2008). Jurassic cyrtocrinids (Cyrtocrinida, Crinoidea) from extra-Carpathian Poland. Palaeontographica Abteilung $A, 285,77-99$.

Salamon, M. A. (2009). Early Cretaceous (Valanginian) sea lilies (Echinodermata, Crinoidea) from Poland. Swiss Journal of Geosciences, 102, 77-88.

Salamon, M. A., Gajerski, A., Gorzelak, P., \& Lukowiak, M. (2007). A new plicatocrinid [tetracrinid?] crinoid, Tetracrinus jagti, from the Cenomanian (Upper Cretaceous) of southern Poland. Neues Jahrbuch für Geologie und Paläontologie Abhandlungen, $245,179-183$.

Salamon, M. A., \& Gorzelak, P. (2010a). Cyrtocrinids (Echinodermata, Crinoidea) from Upper Jurassic Štramberk-type limestones in southern Poland. Palaeontology, 53, 869-885.

Salamon, M. A., \& Gorzelak, P. (2010b). Late Cretaceous crinoids (Crinodea) from Eastern Poland. Palaeontographica Abteilung A, 291, 1-43.

Sieverts-Doreck, H. (1952). In Moore, R..C., Lalicker, C. G.\& Fischer, A. G. (Eds.), Invertebrate fossils. New York, Toronto, London: McGraw-Hill, 766 pp.

Sieverts-Doreck, H. (1964). Über Neufunde von Plicatocriniden im schwäbischen Jura. Jahresbericht und Mitteilungen des oberrheinischen geologischen Vereins N. F., 46, 133-147.

Sieverts-Doreck, H. (1967). Über einen Isocriniden-Kelch aus dem "Baireuthischen-Jurakalk" und eine verwandte Form aus dem schwäbischen Malm. Jahreshefte des Vereins für vaterländische Naturkunde in Württemberg, 122, 92-97.

Sieverts-Doreck, H. (1981). Nachweis von Balanocrinus subteroides, Familie Isocrinidae, im Ober-Pliensbachium der Herforder Liasmulde. Bericht des Naturwissenschaftlichen Vereins Bielefeld, 25, 177-192. 
Simms, M. J. (1989). British Lower Jurassic crinoids. Monograph of the Palaeontographical Society, London, Publication 581, $103 \mathrm{pp}$.

Thuy, B., Gale, A. S., \& Reich, M. (2011). A new echinoderm Lagerstätte from the Pliensbachian (Early Jurassic) of the French Ardennes. Swiss Journal of Palaeontology, 130, 173-185.

Zatoń, M., Salamon, M. A., \& Kaźmierczak, J. (2008). Cyrtocrinids (Crinoidea) and associated stalked crinoids from the Lower/
Middle Oxfordian (Upper Jurassic) shelfal deposits of southern Poland. Geobios, 41, 559-569.

Žítt, J. (1980). Comatulid crinoids from the Lower Cretaceous of Štramberk (Czechoslovakia). Časopius pro mineralogii a geologii, roč. 25( ̌̌. 2), 25-135.

Zittel, K. A. von. (1876-80). Handbuch der Palaeontologie, Band 1, Palaeozoologie, Abt. 1, 765 pp. 